INTER NATIONAL MONETARY FUND
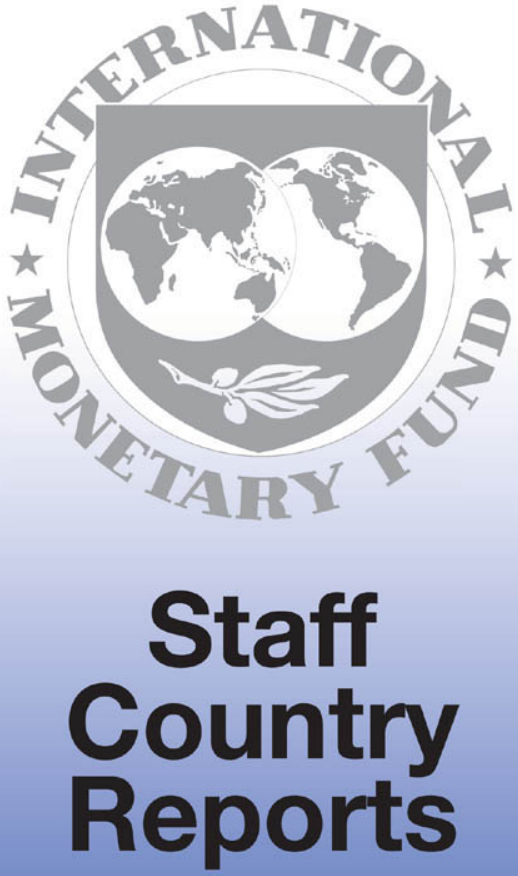
C2000 International Monetary Fund

February 2000

IMF Staff Country Report No. 00/23

\title{
Switzerland: Staff Report for the 1999 Article IV Consultation
}

This report was prepared by a staff team of the International Monetary Fund following discussions with the officials of Switzerland on economic developments and policies. The report was then considered by the IMF's Executive Board in the context of the MMF's periodic consultation with Switzerland, as required under Article IV of the IMF Articles of Agreement. The views expressed in the staff report itself are those of the staff team and do not necessarily reflect the views of the Executive Board of the IMF or of the authorities of Switzerland; a supplementary statement by IMF staff may also be included. The views of the Executive Board as expressed in the discussion of the Article IV consultation report and as summarized in a Public Information Notice (PIN) are also included. In addition, a statement by the member country authorities may be appended. Further background documentation prepared by IMF staff for the consultation may be published separately at a later date. The policy of publication of Article IV staff reports allows for the deletion of market sensitive information.

This Article IV staff report is published-both in hard copy and on the IMF's website (http://www.imf.org) - as part of a pilot project. To assist the IMF in evaluating the pilot project for release of Article IV staff reports, reader comments on the staff report are invited prior to October 5, 2000, and may be sent by e-mail to Pilotproject@imf.org.

Copies of this report are available to the public from

International Monetary Fund - Publication Services 700 19th Street, N.W. - Washington, D.C. 20431

Telephone: (202) 623-7430 - Telefax: (202) 623-7201

Telex (RCA): 248331 IMF UR

E-mail: publications@imf.org

Internet: http:/www.imf.org

Price: $\$ 15.00$ a copy

\author{
International Monetary Fund \\ Washington, D.C.
}


INTERNATIONAL MONETARY FUND

SWITZERLAND

\section{Staff Report for the 1999 Article IV Consultation}

Prepared by the Staff Representatives for the 1999 Consultation with Switzerland

\section{Approved by Alessandro Leipold and G. Russell Kincaid}

January 24,2000

Contents

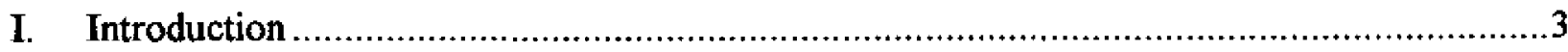

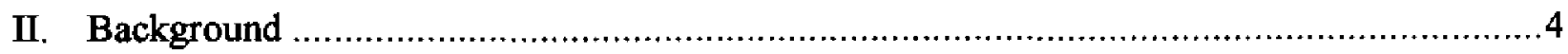

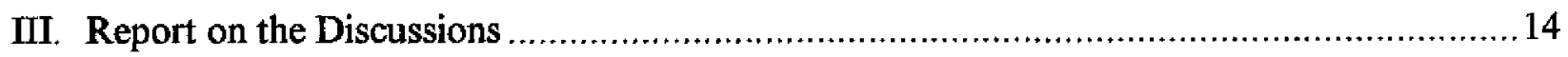

A. Economic Setting and Macroeconomic Policies..........................................14

B. The Framework for Monetary and Exchange Rate Policy .................................15

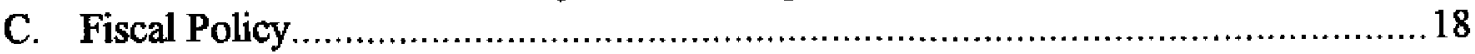

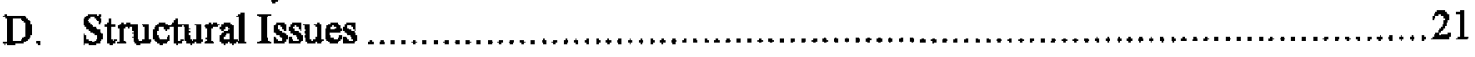

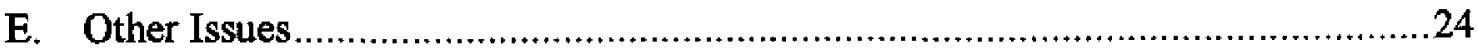

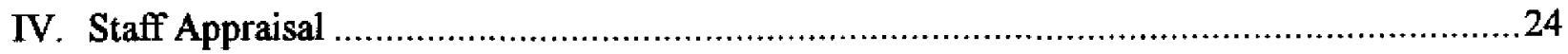

Table

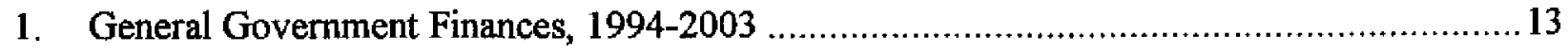

Text Boxes

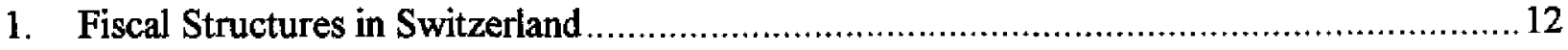

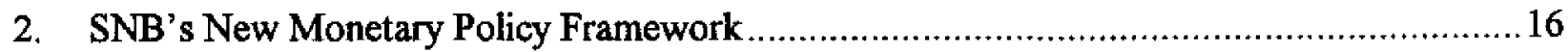

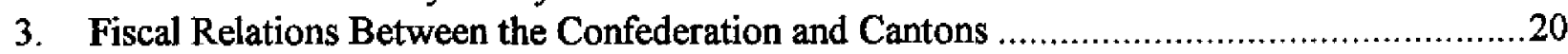

4. Switzerland's Relations with the European Union.................................................22

Figures

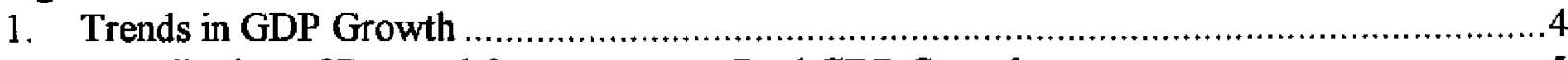

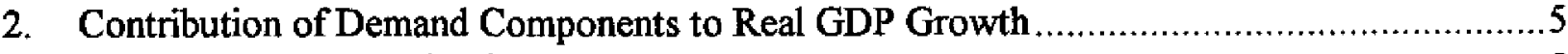

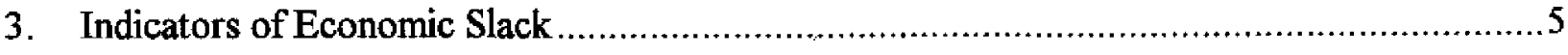


4. International Comparison of Real GDP Levels per Capita ...............................................

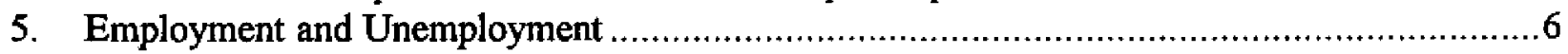

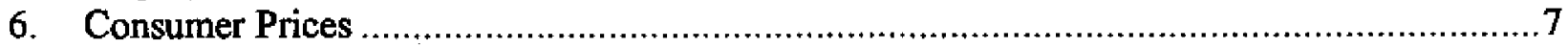

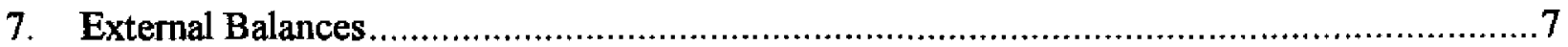

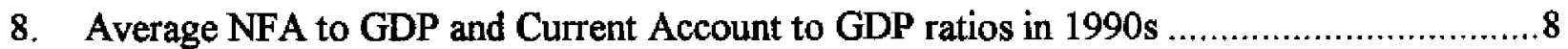

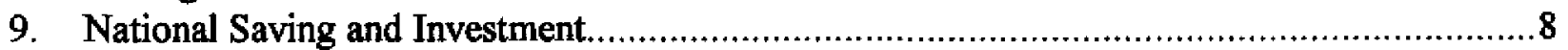

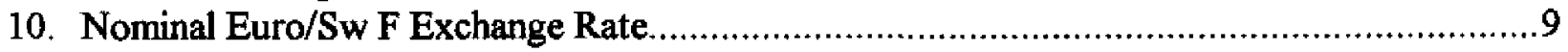

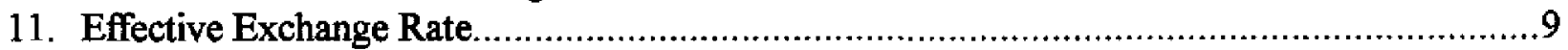

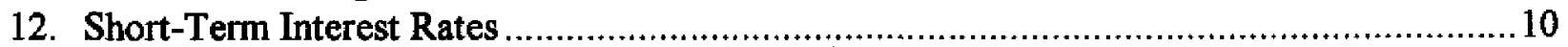

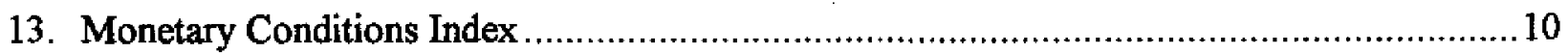

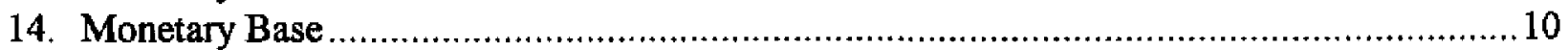

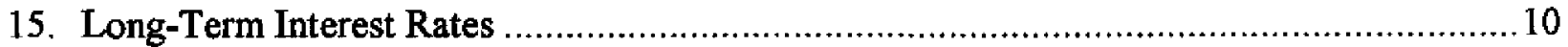

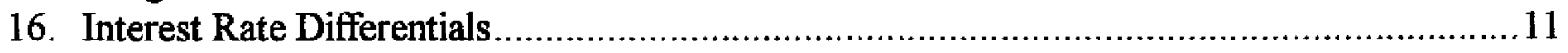

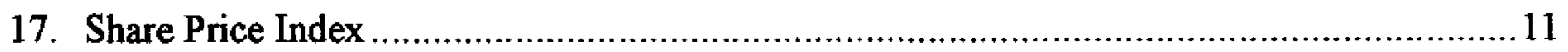

Appendices

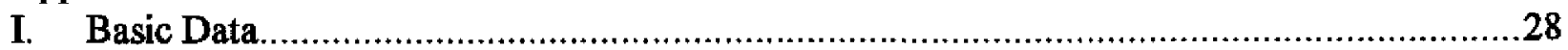

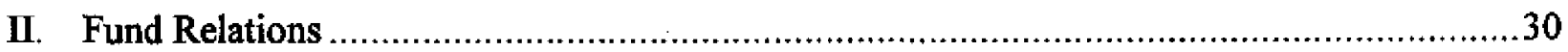

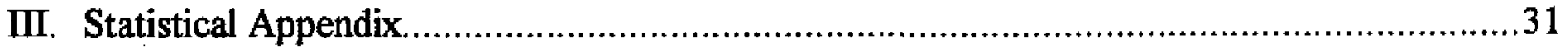




\section{INTRODUCTION ${ }^{1}$}

1. At the conclusion of the previous consultation with Switzerland (EBM/99/18, 2/22/99), Directors commended the authorities for macroeconomic policies that had contributed to improved economic performance after a prolonged period of stagnation. They endorsed the Swiss National Bank's (SNB) accommodative monetary policy, citing continuing economic slack, low inflationary pressures, the prospective shift to fiscal restraint, and downside risks, notably those associated with the crisis in emerging markets and possible upward pressures on the Swiss franc linked to the arrival of the euro. Directors saw scope in this context for further relaxation of monetary conditions if short-term growth prospects were to weaken. Directors welcomed the constitutional commitment to balance the Confederation budget by 2001, and emphasized the need to accelerate and broaden structural reformsespecially of product markets- to strengthen long-term growth prospects.

2. In the event, in April 1999 the SNB eased monetary policy against a background of the European Central Bank's reduction in interest rates and of continuing economic sluggishness, especially in exports. External and domestic conditions and prospects subsequently improved, and in September the SNB shifted to a less accommodative monetary stance.

3. Switzerland has indicated its intention to participate in the pilot project for the release of Article IV staff reports.

4. Switzerland's four-party ruling coalition, in power for 40 years, was confirmed in federal elections held on October 24 . The elections strengthened the position within the coalition of the party opposed to further integration with the EU.

${ }^{1}$ Discussions (in Zürich and Bern from November 5-15, 1999) were held with Federal Councillor Villiger, Minister of Finance; President Meyer, Chairman of the Governing Board of the Swiss National Bank (SNB); senior officials of the federal administration and the SNB; and representatives of a private research institute, financial institutions, a multinational Swiss company, trade unions, and the Swiss Coalition of Development Organizations. Mr. Cippà, Executive Director for Switzerland, attended most meetings. The staff team comprised Messrs. Fetherston (Head), Gagales, Hviding, and Ms. Krajnyák (all EU1).

Switzerland has accepted the obligations of Article VIII, Sections 2, 3, and 4 (Appendix II) and maintains an exchange system that is free of restrictions on payments and transfers for current international transactions. It has subscribed to the Fund's Special Data Dissemination Standard (SDDS) and publishes and provides to the Fund timely and comprehensive economic data that are generally adequate for surveillance; however, statistical deficiencies exist in some areas (Appendix III). 


\section{BACKground}

5. With the economic upswing regaining momentum, the main issues related to activity are the amount of remaining slack and the prospects for improving long-term growth performance. For the first half of the 1990s the economy had been mired in stagnation (Figure 1) that, while partly cyclical, extended a weak long-term growth record since the mid-1970s. Following the adoption of less restrictive policies, the economy appeared by mid-1997 to be entering a strong (by Swiss standards) cyclical upswing. However, the emerging markets crisis and the associated EU slowdown triggered a slump in external demand (export growth declined from 17 percent in 1997 to practically nil in 1998$)^{2}$ (Figure 2), and GDP growth fell from a peak rate of 3.7 percent in mid-1997 to 1 percent through mid-1999. In the third quarter of 1999, however, activity picked up as exports recovered and domestic demand strengthened; the staff estimates growth for the year at 1.4 percent, close to potential

Figure 1. Trends in GDP Growth

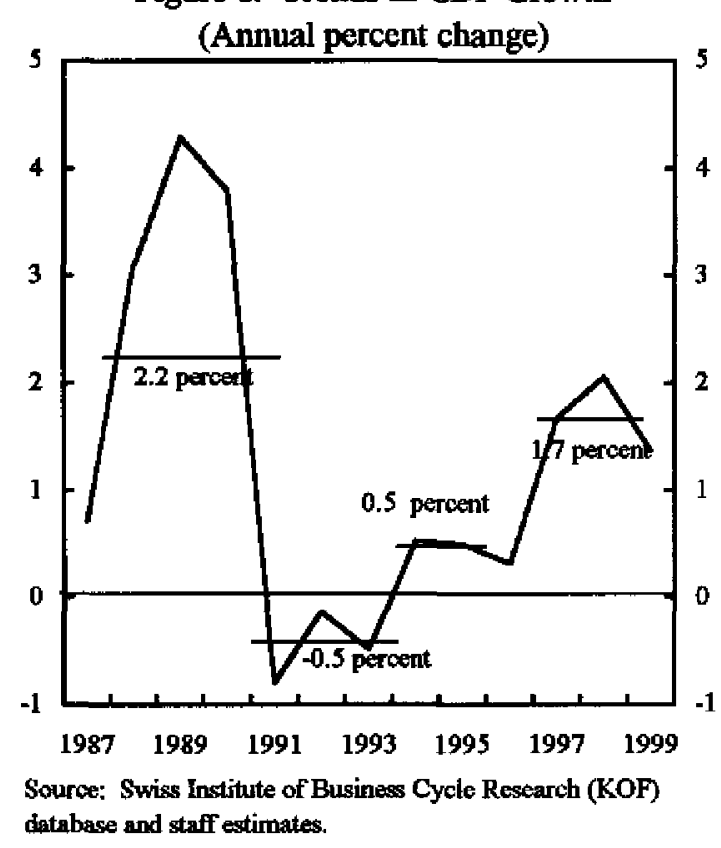
(11/2 percent). Estimates of the output gap ${ }^{3}$ in 1999 range from 1 percent (staff) (Figure 3) to about $1 \frac{1}{2}$ percent (SNB). With the export slowdown, capacity utilization in manufacturing has fallen since mid-1998 and is below its long-term average.

${ }^{2}$ The EU and emerging markets in Asia and Eastern Europe absorb respectively 63 percent, 10 percent, and 5 percent of Swiss merchandise exports.

${ }^{3}$ The staff's estimate of the output gap is derived from a production function analysis. Output gap estimates for Switzerland are subject to unusually large margins of uncertainty reflecting the asymmetric and highly variable duration of recessions and expansions and occasional significant revisions of output data. 
Figure 2. Contribution of Demand

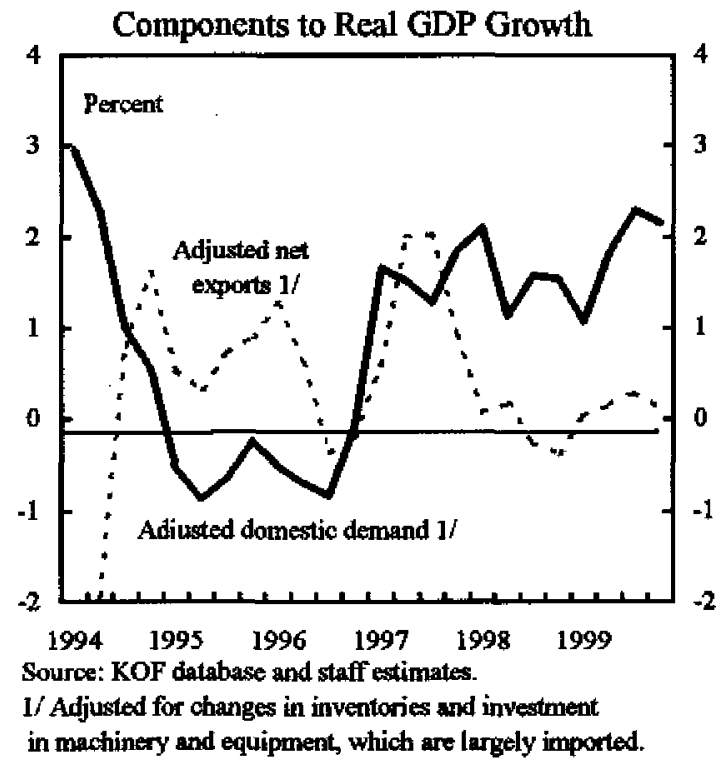

Figure 3. Indicators of Economic

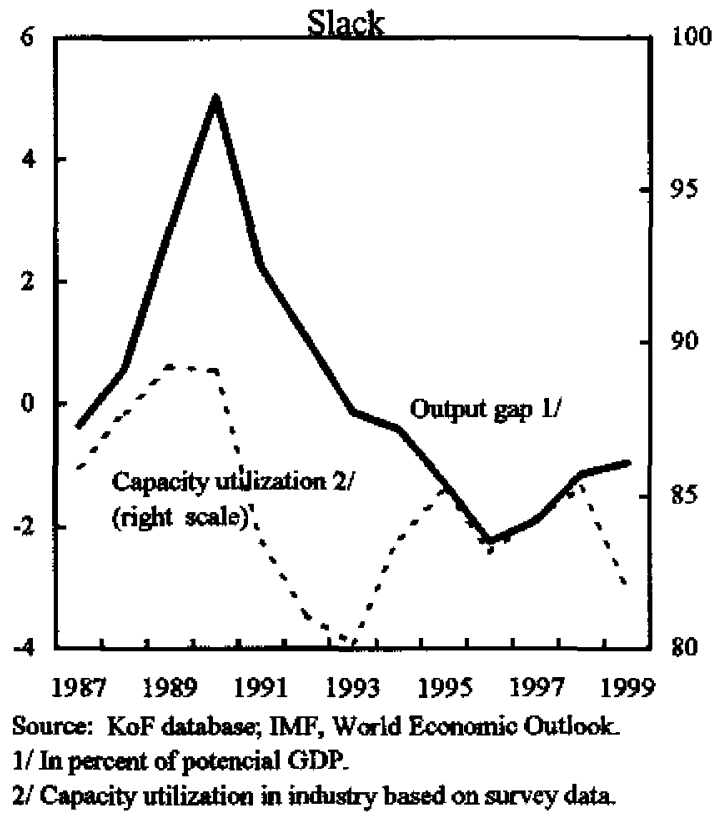

6. For the past quarter century, Switzerland's real per capita growth rate has been substantially slower than in most other industrial countries (Figure 4). During 1976-98, the per capita growth rate was 1 percent per annum, compared with an industrial country average of about $2 \frac{1}{4}$ percent, and total factor productivity grew by an average of $1 / 2$ percent in Switzerland compared to 1 percent in the G-7 countries. ${ }^{4}$ The poor aggregate productivity growth appears mainly attributable to product market rigidities and slow productivity growth in the "sheltered" private sectors (agriculture, construction, and nonfinancial services), ${ }^{5}$ which account for more than a third of GDP. ${ }^{6}$

Figure 4. International Comparison of Real GDP Levels per Capita

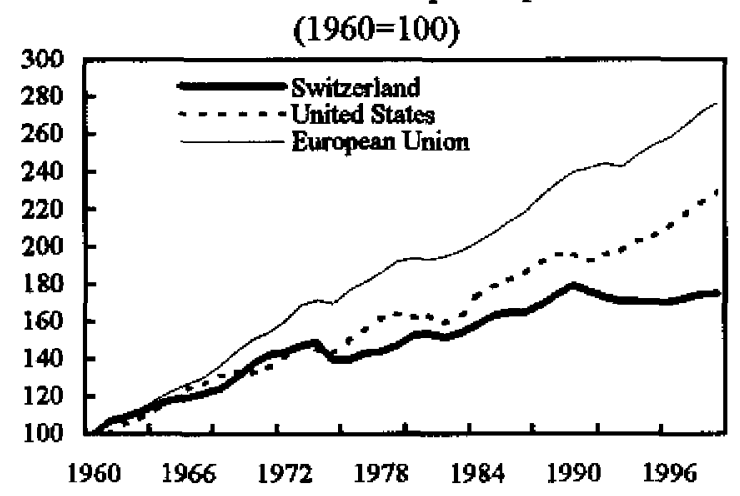

${ }^{4}$ These issues were analyzed in SM/98/40. Recent developments-with Swiss growth rates rising but still $1 / 2-1$ percent lower than in the euro area-do not change these conclusions.

${ }^{5}$ Switzerland's relatively slow growth may, however, partly reflect a catch-up effect on the part of other countries as Switzerland is one of the richest countries in the world. In terms of the purchasing power of its GDP per capita Switzerland was in 1998 below only Luxembourg, the United States, and Singapore. In addition, the above calculations may underestimate the improvement in Swiss welfare since the mid-1970s. First, the purchasing power of Swiss

(continued...) 
7. Unemployment has declined rapidly to 2.4 percent of the labor force in November 1999 from its 1997 peak of over 5 percent (Figure 5). In its early stages, the decline was attributable mainly to 1996-97 changes in labor market policies-notably a requirement to participate in active labor market programs (ALMPs) - and increased use of "intermediate" employment (jobs with a temporary wage subsidy). More recently, however, rising labor demand has been the main factor (employment, excluding subsidized jobs, rose by $11 / 4$ percent in 1998 and by $3 / 4$ percent in the year to the third quarter of 1999). The staff and authorities estimate the structural rate of unemployment at about 2 percent, $1 / 2$ percentage point below the actual rate; however, data on "jobseekers" (registered unemployed plus the socalled registered non-unemployed, notably those enrolled in ALMPs and in intermediate employment) suggest a degree of labor market slack about twice as large. Swiss labor supply is in any event relatively elastic, reflecting the role of foreign workers. ${ }^{7}$ While surveys indicate increasing reports of shortages of

Figure 5. Employment and Unemployment (Seasonally adjusted)

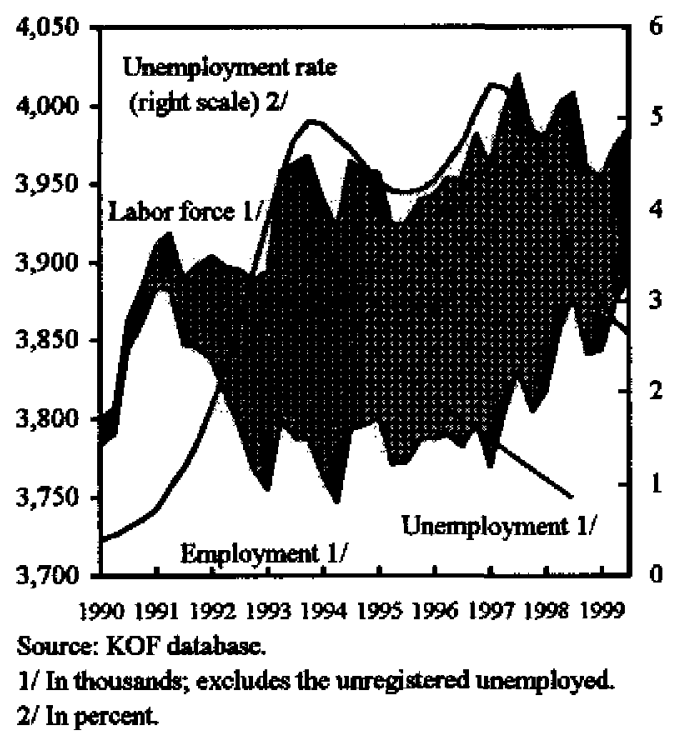
skilled labor, the incidence of these reports is still below its level at the start of the previous upswing in the $1980 \mathrm{~s}$.

8. Inflation has edged up from exceptionally low levels (Figure 6). CPI inflation rose

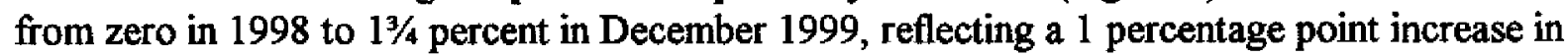

incomes has increased significantly since the mid-1970s, due to terms of trade gains amounting to some 30 percent. Second, financial service sector growth may also have been underestimated, reflecting the accounting convention of treating banking services as mainly intermediate consumption (affecting in particular small countries which are large international financial centers, such as Switzerland and Luxembourg). (See, for example, George Als, 1998, "The Nightmare of Economic Accounts in a Small Country with a Large Intemational Banking Sector," The Review of Income and Wealth, 34, No.1, pp. 101-110.)

${ }^{6}$ Labor productivity growth in these sectors averaged $1 / 2$ percent per annum during 1976-96, compared with $2 \frac{1}{2}$ percent in manufacturing. Rigidities in the sheltered sectors contribute to Switzerland's high price level and raise costs for other sectors.

${ }^{7}$ Employment of foreign workers accounts for a quarter of total and exhibits a pronounced cyclical pattern. During the protracted 1991-97 recession, for example, this category of employment declined by about 9 percent while domestic employment was virtually unchanged. 
the VAT rate in January 1999, sharply higher world oil prices, and higher rents associated with improving housing market conditions. "Core" inflation (CPI inflation excluding indirect taxes and energy) is estimated by staff to have increased over the same period from about $1 / 4$ percent to about $3 / 4$ percent.

Figure 6. Consumer Prices

(12-month percent change)

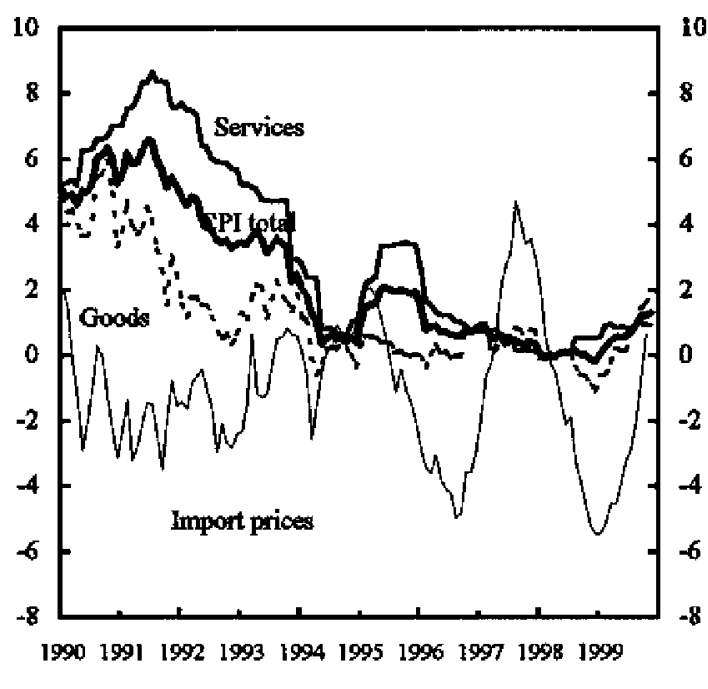

Source: KOF database

9. Switzerland's longstanding current account surplus was above 9 percent of GDP in 1998 and is estimated to have risen further in 1999 (Figure 7). The surpluses have been large by international standards, even after controlling for characteristics thought to influence aggregate savings and investment behavior. Net foreign assets continued to accumulate and are (relative to GDP) the highest among OECD countries (Figure 8). Correspondingly, net capital income generated by external assets - averaging 6 percent of GDP annually in the 1990 srepresents an important component of Switzerland's current account, and more than accounts for the cumulated surpluses. Investment income surged in 1999, buoyed by sharply rising rates of return on external assets. From a savingsinvestment perspective, the current account surplus reflects a high national savings rate that for many years has been close to 30 percent of GDP and an investment ratio that since the early 1990 s has remained in the low 20 percent

Figure 7. External Balances (In percent of GDP)

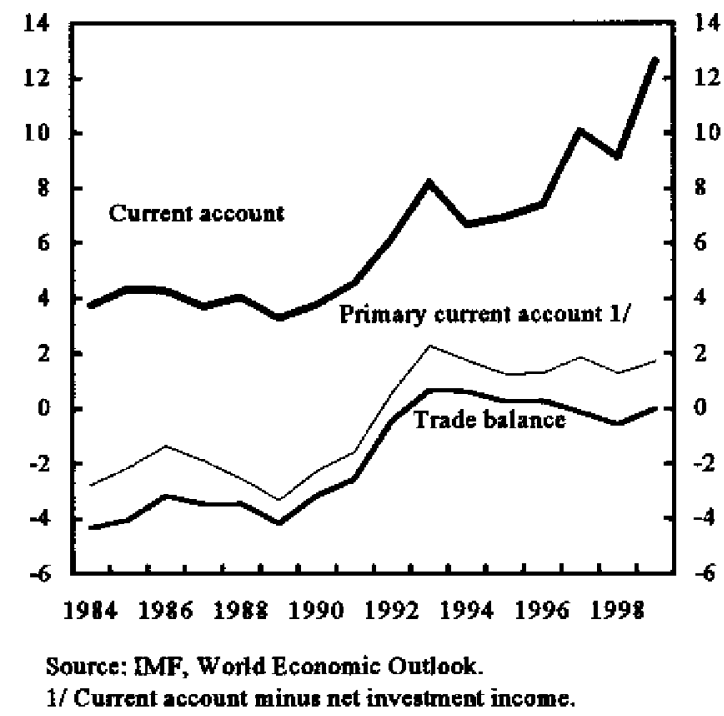


range (Figure 9)-suggesting insufficient opportunities for productive domestic investment of the high level of savings. ${ }^{8}$ A portfolio allocation approach-prompted by the importance of investment income flows in the Swiss current account--indicates that a country with Switzerland's asset composition could be expected to run a longer-run average current account surplus of about 6 percent of GDP. ${ }^{10}$

Figure 8. Average NFA to GDP and Current Account to GDP Ratios in 1990s

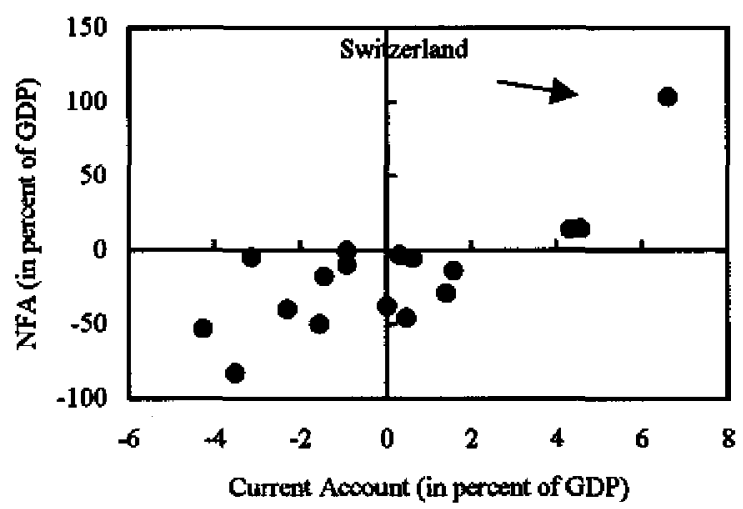

Figure 9. National Saving and Investment

(In percent of Nominal GDP)

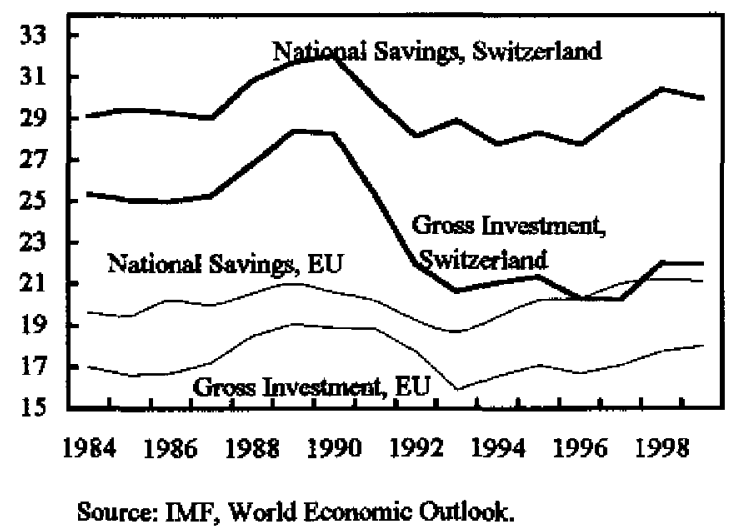

${ }^{8}$ Notwithstanding the high savings rate, Switzerland is also characterized by a bank credit/GDP ratio that is high by international standards and is attributable to the combination of highly developed financial intermediation and low interest rates.

${ }^{9}$ For details of this approach, based on Aart Kraay and Jaume Ventura (2000): "Current Accounts in Debtor and Creditor Countries," Quarterly Journal of Economics, forthcoming, see Chapter II of the accompanying Selected Issues paper. The paper's analysis indicates how the optimal portfolio composition is influenced by the price, relative to internationally traded assets, of a domestic asset which is a source of direct utility services (e.g., housing). If this asset is relatively more expensive, under certain assumptions less of its services will be consumed and its portfolio share will be correspondingly lower, depressing the overall portfolio share of domestic assets. When account is also taken of adjustment costs, cyclical conditions will tend to induce the actual current account to deviate from its average expected level. For instance, after a prolonged recession, the current account surplus would tend to become larger, in line with Switzerland's experience during the 1990s.

${ }^{10}$ An alternative methodology based on estimating longer-run differences between savings and investment puts the implied current account surplus at about 5 percent of GDP. (Guy Debelle and Hamid Faruqee (1996): "What Determines the Current Account? A Cross-Sectional and Panel approach," IMF Working Papers WP/96/58). 
10. The franc has shadowed the euro closely since January 1999, fluctuating narrowly around 1.6 Sw F/euro (Figure 10). With the euro weakening vis-à-vis the dollar and, to a lesser extent, the pound and the yen, the franc has depreciated by about 5 percent in nominal and real effective terms since January 1999, bringing the latter close to its long-term average (Figure 11). The staff's latest multilateral exchange rate assessment exercise based on the macroeconomic balance approach suggested that the franc was weaker than its equilibrium level by about 15 percent, ${ }^{11}$ partly reflecting the euro's weakness against the dollar.

Figure 10. Nominal Euro/Sw F

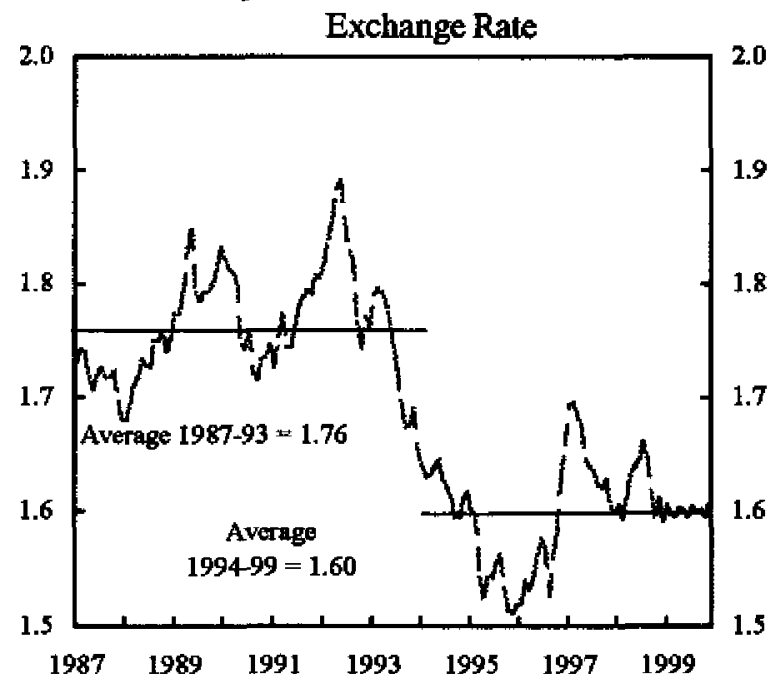

Source: IMF, International Financial Statistics datahase.
Figure. 11 Effective Exchange Rate

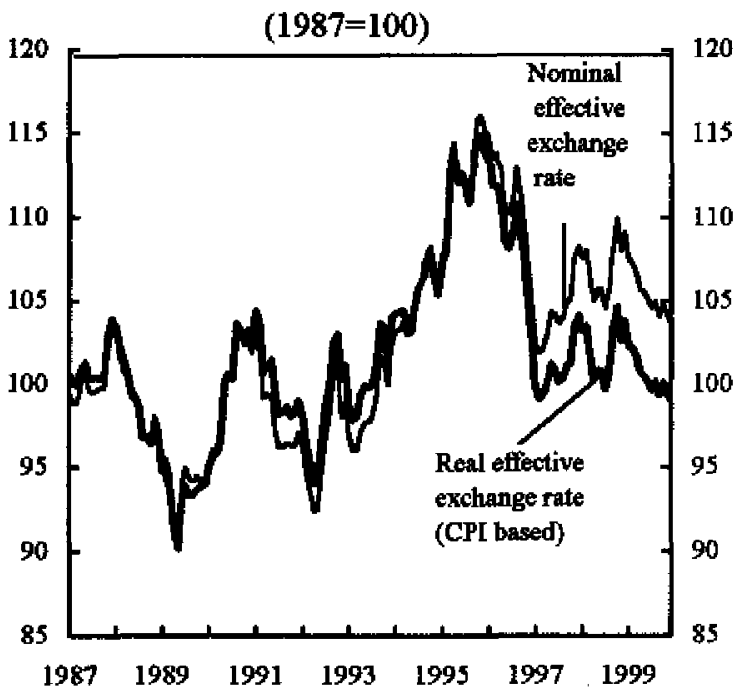

Source: IMF, International Financial Statistics database.

11. Monetary policy has shifted to a more neutral posture. For much of 1999, amidst faltering economic activity, deflation risks, and concern that financial market turmoil or the introduction of the euro could trigger a sharp appreciation of the franc, the SNB maintained an accommodative policy stance. In April 1999 the ECB interest rate cut was matched by a cut in the Swiss discount rate to 0.5 percent (the second lowest after Japan), and in subsequent months both the overnight repo rate and the three-month London interbank (LIBOR) rate were close to 1 percent (Figure 12); the monetary conditions index fell in September to its lowest level since 1997 (Figure 13). Base money remained some 7 percent above its medium-target path (Figure 14). ${ }^{12}$ In September short-term interest rates firmed

${ }^{11}$ In these assessments, deviations greater than 10 percent warrant consideration of the possibility that exchange rates may be misaligned.

${ }^{12}$ A series of velocity shifts in recent years has made developments in base money increasingly difficult to interpret, and its policy role was reduced in 1998-99. 
significantly, with the overnight rate going over 1 percent and the three-month rate rising more sharply to about 2 percent; about 50 basis points (i.e., close to half) of the increase was estimated to reflect the effect of the end-year "Y2K spike." Long-term bond yields recovered from a thirty-year low of 21/2 percent in early 1999 to $3 \frac{1}{2}$ percent in December (Figure 15). Swiss interest rates remain, as they have for many years, substantially lower than elsewhere (about 150 basis points below comparable euro area rates) (Figure 16). Stock prices, following a strong run-up since 1995 and a sharp correction at end-1998 (Figure 17), remained flat for most of 1999 before turning up at end-year.

Figure 12. Short-Term Interest Rates (In percent)

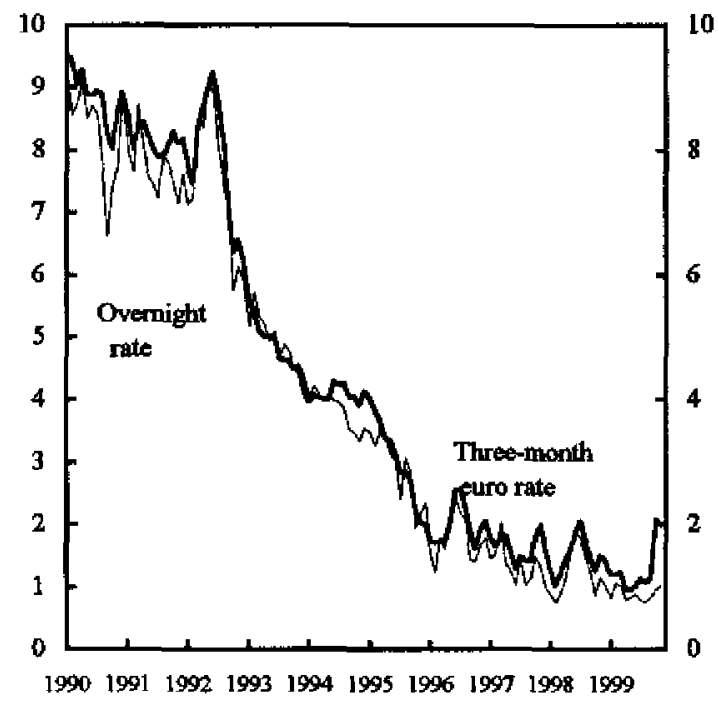

Source: IMF, International Financial Statistics catabase.

Figure 14. Monetary Base

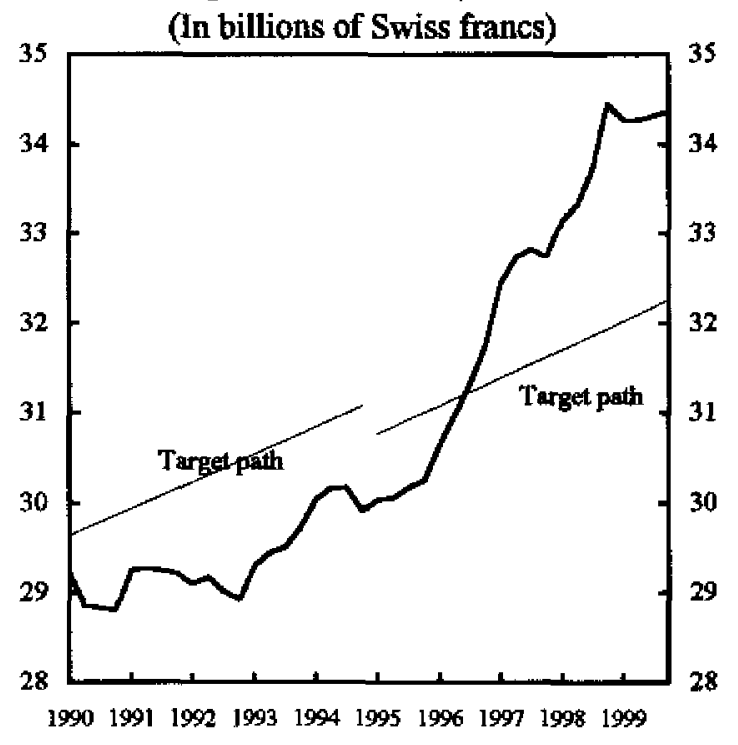

Source: Swiss National Bank, Monthly Bulletin.
Figure 13. Monetary Conditions Index $1 /(1994=1)$

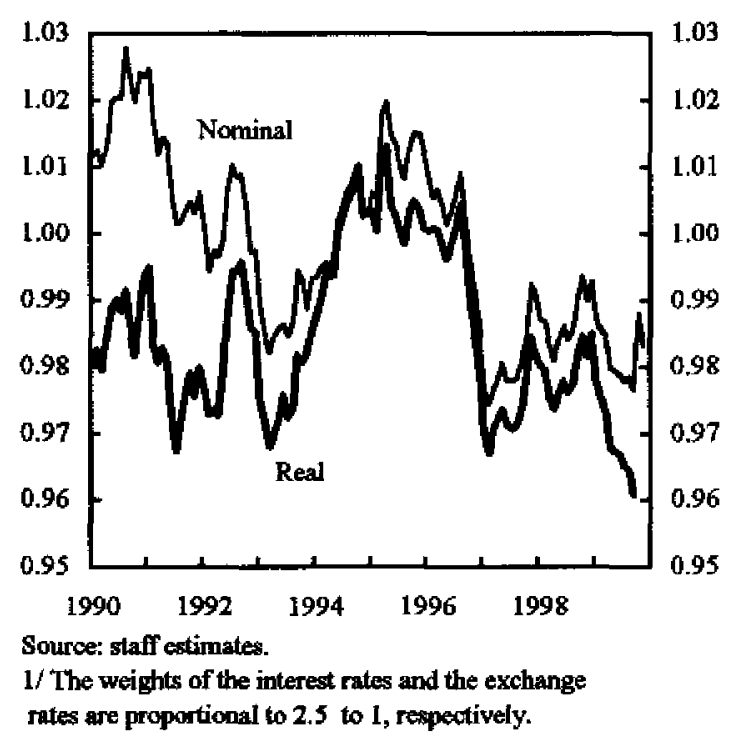

Figure 15. Long-Term Interest Rates

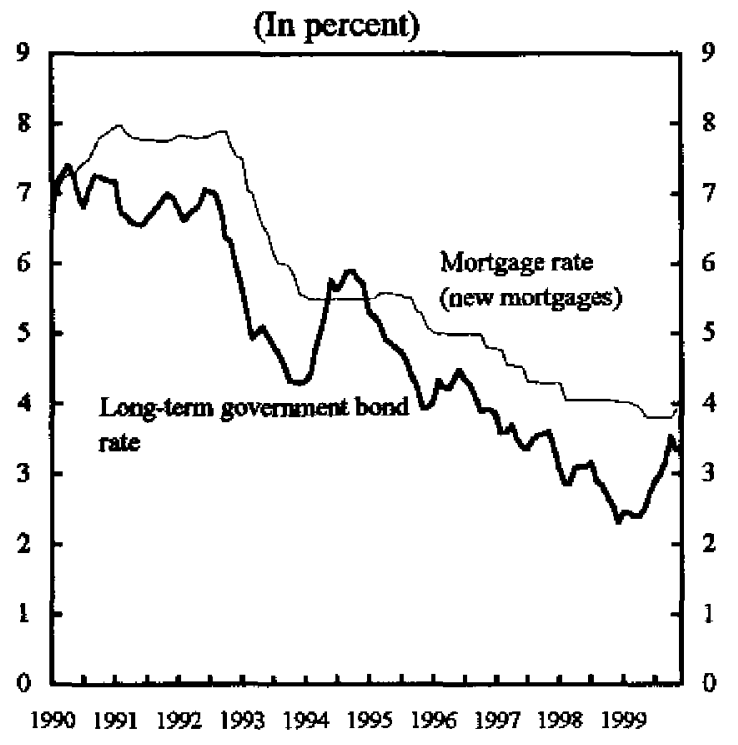

Source: KOF database. 
Figure 16. Interest Rate Differentials

(Germany - Switzerland)

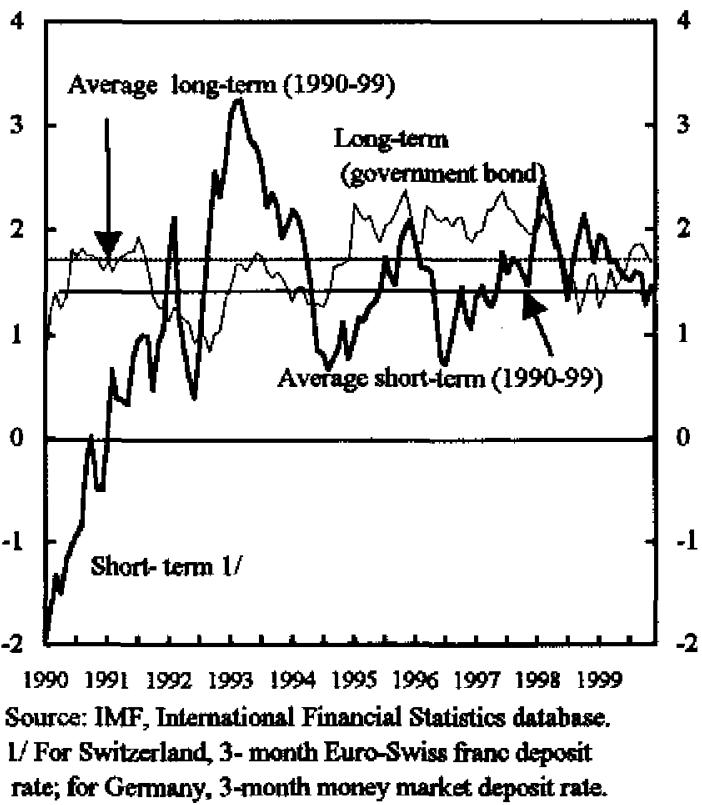

Figure 17. Share Price Index $(1990=100)$

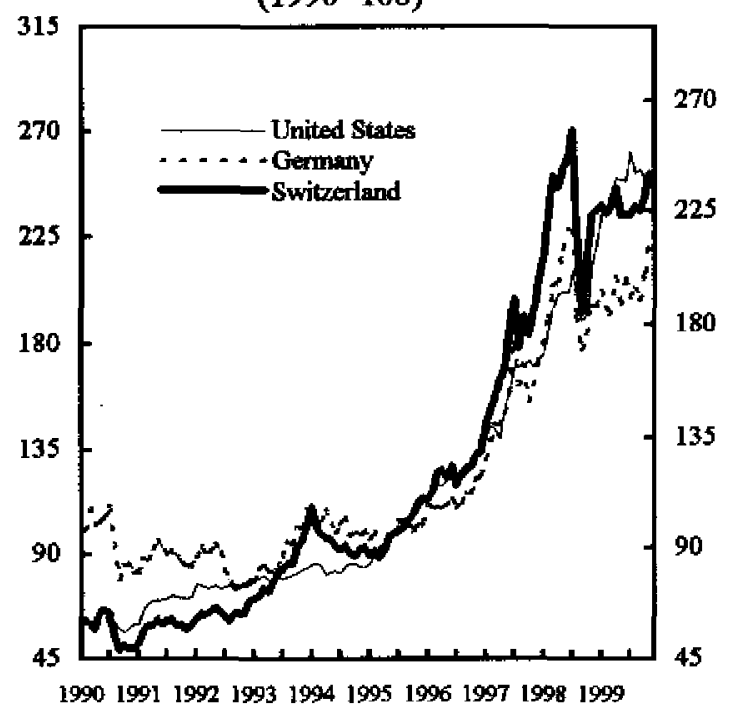

Source: KOF database.

\section{Following a series of deficits and a rising debt ratio through the $1990 \mathrm{~s}$, fiscal} policy is now guided by the June 1998 constitutional commitment to balance the Confederation budget by 2001. The Confederation deficit in 1999 is estimated to be below budget (11/4 percent of GDP) by about $1 / 4$ percent of GDP, reflecting higher revenue and modest overall expenditure savings (higher expenditure related to the Kosovo crisis was offset by lower spending on transport, personnel, defense, agriculture, and interest). The deficit in the general government, including the operations of cantons and communes (Box 1), is estimated at 1.4 percent of GDP, with its structural component about 1 percent of GDP (Table 1). There was a positive fiscal impulse in 1999 that was helpful from a cyclical perspective. ${ }^{13}$ Gross public debt at end-1999 is estimated at 54 percent of GDP.

\footnotetext{
${ }^{13}$ Fiscal impulse calculations on a year-by-year basis are, however, complicated in the Swiss case by several factors, notably: surges in withholding tax revenues in one year followed by associated large refunds in the next (as happened in 1998-99); and the tendency, given the two-year system of income tax assessment prevalent hitherto, for tax collections to be higher relative to GDP (other things equal) in odd years than in even ones.
} 


\section{Box 1. Fiscal Structures in Switzerland}

The Swiss fiscal system includes three levels of government-federal, cantonal, and municipal. The 26 cantons and half-cantons comprise the constituent parts of the federation, and possess full legal sovereignty unless limited by the constitution. Although not sovereign, municipalities also have substantial autonomy. Economically, the three tiers of government are of similar size (on a consolidated basis, each around 12 percent of GDP in 1997).

Although each authority has its own budget, these budgets are linked by intergovernmental transfers.' Taxing powers and expenditure functions are attributed by the Constitution to the different levels of government. While indirect taxes (VAT, excises, and customs duties) are exclusively federal, direct taxes are independently levied and collected by separate administrations of all three levels of government. On the expenditure side, constitutionally defined functions of the lower levels of government are supplemented by delegated functions. Vertical transfers are provided in connection with these delegated functions and cross-cantonal equity objectives. Borrowing is limited by law on the federation level and in many cantons.

Several features of the budget process limit the scope for discretionary fiscal policy and accentuate the need for transparent and efficient fiscal policy rules. First, the budget processes of the different governmental entities are fully autonomous. Second, individual items of budgets must have been previously legislated, and appropriations cannot be introduced in their own right. Third, cantonal and communal budgets, as well as their individual items, can be challenged by "finance referenda."

This institutional setup proved to be conducive to the emergence of a system of fiscal relations characterized by (i) high complexity; (ii) weak automatic stabilizers; and (iii) little policy coordination between the federation and the local governments. ${ }^{2}$

Recent reforms and reform proposals aim at reducing the complexity of the system and strengthening the countercyclical role of fiscal policy, mainly by improving the operation of automatic stabilizers. Notably, reform efforts strive to simplify the fiscal system by formally harmonizing taxation across cantons, and rationalizing fiscal relations between the federation and the cantons (Box 3). Steps towards strengthening the automatic stabilizers include shortening tax collection lags by shifting income tax assessment from a biannual to an annual basis in all cantons by 2001 , and the planned adoption of a new framework for federal fiscal policy. The new framework, which is envisaged to be based on the requirement of balancing the federal budget over the business cycle, would succeed the current constitutional mandate to balance the federal budget by 2001 .

'Paul Bernd Spahn, "Switzerland" (in: Fiscal Federalism in Theory and Practice, edited by Teresa Ter-Minassian, pp. 324-41, IMF (1997)) estimates that about 20 percent of the cantons' revenues comes from the federation, and about 7 percent from the municipalities.

${ }^{2}$ SM/99/31, Chapter III, "Challenges to the Swiss Tax System," which highlights the numerous idiosyncrasies of the tax system, and SM/98/40, Chapter II, "Fiscal Policy Rules and the Business Cycle" which finds that fiscal policy has often been procyclical in the past, emphasize the importance of institutional factors in these developments. 
Table 1. Switzerland: General Government Finances, 1994-2003

\begin{tabular}{|c|c|c|c|c|c|c|c|c|c|c|}
\hline & \multirow{2}{*}{1994} & \multirow{2}{*}{1995} & \multirow{2}{*}{1996} & \multirow{2}{*}{1997} & \multirow{2}{*}{1998} & \multirow{2}{*}{1999} & \multicolumn{4}{|c|}{ Projections } \\
\hline & & & & & & & 2000 & 2001 & 2002 & 2003 \\
\hline & \multicolumn{10}{|c|}{ (In percent of GDP) } \\
\hline General government budget balance 1/ & -2.8 & -1.9 & -1.9 & -2.4 & -1.1 & -1.4 & -1.2 & -1.4 & -1.2 & -0.8 \\
\hline Confederation & -1.9 & -1.3 & -1.6 & -1.5 & -0.7 & -0.9 & -0.6 & -0.6 & -0.3 & 0.1 \\
\hline Margin below the constitutional ceiling & $\ldots$ & $\cdots$ & $\ldots$ & $\ldots$ & $\ldots$ & 0.6 & 0.2 & -0.1 & 0.1 & 0.5 \\
\hline Cantons & -1.0 & -0.5 & -0.6 & -0.8 & -0.2 & -0.3 & -0.4 & -0.5 & -0.5 & -0.5 \\
\hline Communes & -0.2 & -0.2 & -0.1 & -0.2 & -0.1 & -0.1 & -0.1 & -0.1 & -0.1 & -0.1 \\
\hline Social security system & 0.4 & 0.2 & 0.4 & 0.1 & -0.1 & 0.0 & -0.1 & -0.3 & -0.3 & -0.3 \\
\hline General govemment gross debt & 45,0 & 46.9 & 49.3 & 51.5 & 53.8 & 54,0 & 53.4 & 52.8 & 52.3 & 51.4 \\
\hline \multicolumn{11}{|l|}{ Memorandum items: } \\
\hline General government revenue & 35.7 & 36.5 & 37.1 & $\mathbf{3 7 . 0}$ & 38.2 & 37.6 & 37.2 & 36.6 & 37.0 & 37.5 \\
\hline General government expenditure & 38.7 & 38.4 & 39.3 & 39.4 & 39.3 & 39.1 & 38.4 & 38.1 & 38.1 & 38.3 \\
\hline Structural budget balance $2 /$ & -2.6 & -1.6 & -1.4 & -1.3 & -0.4 & -1.1 & -1.0 & -1.3 & -1.0 & -0.7 \\
\hline Primary structural balance $2 /$ & -0.5 & 0.5 & 0.8 & 1.0 & 1.7 & 0.9 & 1.2 & 1.1 & 1.3 & 1.7 \\
\hline Output gap & -0.4 & -1.3 & -2.2 & -1.9 & -1.1 & -1.0 & -0.5 & -0.2 & -0.2 & -0.2 \\
\hline Real GDP growth & 0.5 & 0.5 & 0.3 & 1.7 & 2.1 & 1.4 & 2.0 & 1.8 & 1.6 & 1.5 \\
\hline
\end{tabular}

Sources: Data provided by the authorities; and staff estimates and projections. These include measures incorporated in the 2000 budget but not additional measures ( 0.15 percent of GDP) that are estimated to be needed to observe the constitutional ceiling in 2001.

1/ Cash basis; projections include increase of VAT rate by 1 percentage point in 1999 to consolidate social security finances and the measures of the Stabilisierungsprogramm 98 .

2/ Staff estimates based on general government data including social security. 


\section{REPORT ON THE DISCusSions}

\section{A. Economic Setting and Macroeconomic Policies}

13. The consultation discussions focused on short-term prospects, and the implications for macroeconomic policies; the authorities' plans for new medium-term monetary and fiscal policy frameworks; and structural reforms to boost long-term growth performance.

\section{Short-term macroeconomic prospects are seen as favorable, but not without} risks. The authorities, private forecasters, and staff expect growth to pick up from 11/4-11/2 percent in 1999 to above-trend rates close to 2 percent in 2000 and 2001 on the strength of faster growth in exports, buoyed by higher demand from the EU and Asia, and investment. ${ }^{14}$ Risks to the outlook were seen as somewhat better balanced than a year ago. The main risk was of a hard landing of the U.S. economy which would affect external demand and also could be accompanied by disruptive financial market pressures (such as a sharp appreciation of the Swiss franc); ${ }^{15}$ on the upside, a more vigorous upswing of EU activity than currently envisaged is possible. Inflation forecasts for 2000 are in the range of 1 to $1 \frac{1}{2}$ percent, with the SNB projection at the upper end; while the 1999 increases in VAT and oil prices will drop out of the calculation and deregulation should lead to price reductions for utilities and food, prices of services are expected to continue rising in response to private consumption demand, with rents in particular affected by a tightening housing market and higher interest rates. ${ }^{16}$ All in all, the staff projects inflation of $1 \frac{1}{3}$ percent in 2000 , close to 1 percent on a core basis. For 2001, all forecasters see inflation drifting slightly upward (by about $1 / 4$ percent) as the upswing continues and additional slack is absorbed, but remaining within the SNB's definition of price stability (2 percent or less).

\section{With the Confederation's fiscal policy constitutionally set on a medium-term} path to balance, the macroeconomic policy discussions focused on the SNB's September 1999 shift to a less accommodative stance and the policy requirements looking forward. The SNB representatives explained that with the strengthening of economic activity and prospects both in Switzerland and in its EU trading partners during the summer of 1999, the highly accommodative policy stance in effect since April had been considered to be no longer compatible with medium-term price stability. The SNB thus announced in

${ }^{14}$ In 1999, significant purchases of passenger aircraft $\longrightarrow$ which are imported and do not affect demand for domestic output — affect the picture presented by data for aggregate investment.

${ }^{15}$ In past episodes of significant weakening of the U.S. dollar, the Swiss franc has tended to appreciate against European currencies as well as the dollar.

${ }^{16}$ Rents under existing contracts are subject to adjustment in line with changes in mortgage interest rates. The extent to which such adjustments are made depends on the strength of rental demand. 
September an intention to shift to a more neutral stance and acted shortly thereafter, focusing on three-month money market rates.

16. The staff queried the timing and presentation of the monetary tightening. On the former, the risks to price stability had not appeared imminent and there could have been scope for waiting until the upswing was clearly established-the more so since the stance of fiscal policy in 2000 was set to be somewhat contractionary. On presentation, the September action (as distinct from the broad intention to shift at some point) had not been publicized or explained at the time, and with the Y2K spike coming into play at the same point, there had been confusion among commentators and market participants. SNB officials agreed that with hindsight the matter could have been handled with greater transparency; in any event, following the ECB's action in early November the SNB had clarified that it had already moved and saw no need for further steps at that point.

\section{Looking forward, the staff and authorities agreed that further monetary} tightening is likely to be needed at some stage if the upswing unfolds in line with expectations. In the view of the staff, current conditions did not require immediate action, although it was necessary to remain vigilant for indications of possible inflationary pressures such as accelerating earnings growth or high capacity utilization. Following the introduction of its new policy framework (described below), the SNB announced in January that, in view of increasing signs of an improved cyclical position, it would target the three-month LIBOR rate in the upper part of its $1.25-2.25$ percent range, implying a slight tightening of the monetary policy stance relative to late 1999 .

\section{B. The Framework for Monetary and Exchange Rate Policy}

\section{The SNB representatives explained the considerations underlying the new} monetary policy framework that was made public on December 10 (Box 2). It had been clear for some time that base money was no longer suitable as an intermediate target for monetary policy, and indeed the SNB's policy statements of the past two years had highlighted the increasing attention given to other indicators, in line with earlier advice by staff and other observers. It had been decided to wait until now before articulating the new framework, for several reasons: the medium-term base money path was set to expire at end-1999; time was needed to strengthen the SNB's forecasting capabilities to support a new approach; and at the beginning of 1999 it had been desirable to avoid a change in policy framework that could have faced complications in Swiss markets owing to the introduction of the euro in neighboring countries.

19. The new framework specifies that monetary policy will be primarily geared to the objective of medium-term price stability, defined as a rate of inflation of less than 2 percent (the same objective as that of the ECB). Formal monetary targeting $\rightarrow$ feature of Swiss monetary policy for a quarter century - has been abandoned. The framework is not one of full-fledged inflation targeting, in that the SNB is not formally committed to maintaining 


\section{Box 2. SNB's New Monetary Policy Framework}

After a quarter century of monetary targeting which kept average inflation at 3 percent (at par with Germany), on December 10, 1999 the SNB announced a new monetary policy framework effective from the year 2000 onward. Its main elements are:

- As in the past, monetary policy will be primarily oriented toward price stability, which is now defined as annual CPI inflation of less than 2 percent. Inflation may fluctuate in the short-run due to temporary factors (e.g. unexpected oil price hikes and exchange rate fluctuations) that monetary policy can influence only to a limited extent; however, persistent inflationary and deflationary developments will be countered.

- Monetary policy decisions will be based mainly on the inflation forecast over a three-year horizon. The inflation forecast, which will be published at each year-end, will be based on all relevant indicators, e.g., economic activity, wages, monetary aggregates, and exchange rates. Thus M3 will continue to play an important role as an indicator of longer-term inflation developments. The three-year forecasting horizon reflects the length of the monetary transmission mechanism in Switzerland. Currently, inflation is forecast by the SNB to rise to 1.5 percent in $2000,1.7$ percent in 2001 and 1.8 percent in 2002 .

- The operating target of monetary policy will be a target range for the three-month Swiss franc LIBOR. The target range, which has a width of 1 percentage point, is currently set at $11 /-21 / 4$ percent. The SNB will also indicate where within the target range it expects the three-month LIBOR to be. The target range will be assessed periodically and adjusted as needed.

- Open market operations will be mainly conducted with repos with maturities ranging from one to several weeks. These will be supplemented with sales of government paper, foreign exchange swaps and, in case of unforeseen liquidity bottlenecks, Lombard loans.

- The SNB will continue to publish quarterly an assessment of monetary policy.

The inflation forecast is intended to communicate the SNB's long-ferm monetary policy stance whereas the target range on the LIBOR to indicate the monetary policy stance in the shorter term. Short-term repo rates are not intended to serve as monetary indicators: the SNB intends, in principle, to act daily in the market and take a flexible approach in setting repo rates.

Despite similarities with inflation targeting, the new framework differs from it in one important respect, namely, it does not contain an institutional commitment to an inflation target as the overriding objective of monetary policy. Unlike most other inflation targeting central banks that suffered from a credibility deficit prior to the introduction of inflation targeting, the SNB considers that it has a demonstrated commitment to price stability and an institutional commitment is therefore not seen as vital. As compared with the $E C B$, the new framework differs in three important respects: inflation forecasts are published (the ECB intends to begin publishing economic forecasts, including for inflation); there is no second pillar (monetary intermediate target); and the interest rate target is specified as a range rather than as a value. Compared to the pragmatic monetary targeting that it replaces, ${ }^{1}$ the new framework provides a more transparent platform for discussing and communicating monetary policy; is robust to financial innovation-related velocity shocks which plagued Swiss monetary targeting over the past decade; and, like its predecessor, grants the SNB room for "disciplined discretion." Key challenges in the implementation of the framework include the reliability of inflation forecasts over a long horizon, the degree to which policy will adjust to shocks, and the use as operating target of the 3-month Swiss franc Libor rate with a relatively wide range.

${ }^{1}$ The Swiss experience with monetary targeting was reviewed in SM/99/31.

${ }^{2}$ T. Laubach and A. Posen (1997), Disciplined Discretion: the German and Swiss Monetary Targeting in Operation, FRBNY, Research Paper 9707. 
inflation within a given band (as such, it is similar to the inflation "pillar" of the ECB's framework). The SNB has made plain that price stability entails countering deflation as well as inflation, but given uncertainties (for example about the estimated bias in the CPI) had chosen not to define a precise lower limit. In the interest of transparency and continuity, the SNB had chosen to focus on the CPI and not on alternative measures that might exclude elements such as energy and indirect taxes. The SNB will publish, once a year, its forecast for inflation over the next three years and analyze on a continuing basis the factors that are important elements in the forecast. These include M3, economic and labor market developments, and the exchange rate- a list which the staff suggested, given the importance of policy mix considerations, could usefully include explicitly the stance of fiscal policy. The inflation forecast reflects input from several models, which have not so far been made public, and incorporates announced policies. The framework introduces an announced band for threemonth LIBOR rates (1.25-2.25 percent), with the authorities also signalling their objective for the position of the LIBOR rate within the band; these policies can be changed by decision of the SNB's Governing Board (which meets weekly). The SNB explained that the LIBOR rate was selected because of this market's depth and significance for refinancing of Swiss banks and companies; daily operations will be conducted through repos and/or swaps in the domestic market. A wide band was chosen in order to retain scope for market developments to trigger interest rate changes within the band, and to allow room also for interest rates to act as a shock absorber for exchange market disturbances. The staff observed that these features underscored the desirability of clear and frequent communication with markets, and welcomed the SNB's intention to continue publishing a quarterly statement of monetary policy conclusions, including commentary on developments in the indicators underlying the annual inflation forecast.

20. While the exchange rate would be an important variable for the new framework given Switzerland's highly open economy, the SNB had concluded that exchange rate targeting did not offer a serious alternative. Under such an approach Switzerland would lose the benefits both of low interest rates and of the ability to tailor monetary policy to its own needs - factors which in the SNB's view outweighed possible gains from greater exchange rate stability. The SNB had sought to make clear that the high degree of stability observed so far between the Swiss franc and the euro-belying earlier concerns that the introduction of the euro could trigger large capital flows and upward pressure on the Swiss franc-reflected the similar cyclical positions of the Swiss and euro area economies, their close trade links, similar inflation objectives, and the absence of financial market disturbances; at the same time, they had publicly stated that maintenance of Switzerland's monetary autonomy may imply larger fluctuations against the euro than observed to date.

\section{The authorities did not view Switzerland's large external current account} surplus as presenting a major policy issue. The surplus was a structural feature that reflected the positive net foreign asset position rather than trade imbalances, and there was little indication that the surplus as such was a source of appreciation pressures. The staff noted that its portfolio allocation analysis suggested a possible link between the surplus and another 
long-established Swiss economic feature-the high level of domestic prices ${ }^{17}$ especially for nontraded goods, with the latter serving to discourage domestic investment. This in turn pointed to the desirability of steps to reduce product market rigidities.

\section{Fiscal Policy}

22. The cornerstone of Swiss fiscal policy in the near-term is provided by the June 1998 constitutional amendment that specifies annual limits on the Confederation budget deficit en route to balance in 2001. This framework stipulates annual deficit ceilings equivalent to $3 / 4$ percent of GDP in 2000 , and $1 / 4$ percent of GDP in $2001 .^{18}$ On present policies, the budget was on track to observe these limits in 1999 and 2000. For 2001, some further action (estimated at 0.15 percent of GDP) was expected to be needed, and the authorities planned during 2000 to propose expenditure savings for this purpose. The implied fiscal policy stance is a modest withdrawal of stimulus in $2000(0.3$ percent of GDP) and neutral in 2001. ${ }^{19}$

23. The authorities are preparing a new constitutional amendment to strengthen the framework for fiscal policy at the Confederation level after 2001. The guiding principle of this amendment is that the budget would be balanced over the cycle, with the automatic stabilizers allowed to operate. To this end, their preferred operational approach-welcomed by the staff-was to specify a medium-term path of expenditure limits consistent with the goal of budget balance, the projected rate of growth of potential and an inflation rate compatible with the goal of price stability. With spending kept to these limits, revenues and the deficit would be allowed to fluctuate with the cycle. Moreover, with tax collections in almost all cantons expected by 2001 to have shifted to a current-year basis, the automatic stabilizers (at least at the Confederation level) could be expected to operate more effectively than in the past. Admittedly this would not address tendencies at lower levels of government toward procyclical policies of balancing budgets year-by-year, but the authorities felt that it was not practical, given data lags and political sentiment, for the new fiscal policy framework for the Confederation to take account of this.

24. The authorities acknowledged the complexities and costs of the tax system, while pointing to the constraints resulting from Switzerland's devolved system of government. Recent steps have concentrated on the goal of formal tax harmonization (i.e., common tax

${ }^{17}$ Swiss prices on average are about 40 percent above the OECD mean.

${ }^{18}$ The federal budget is considered to be balanced if the deficit is less than Sw F 2.5 billion ( $1 / 4$ percent of GDP) in 2000 and no more than 2 percent of revenue thereafter.

${ }^{19}$ Structural balance projections in Table 1 are based, in line with WEO conventions, on current policies and do not include the additional measures estimated to be needed in 2001 to balance the confederation budget. 
base definitions and administrative and criminal procedures), although the authorities acknowledged that the present legal framework does not provide a comprehensive basis. They noted in this respect the complex process for changing tax laws (requiring legislative action by each canton) and indicated that they were considering developing a uniform federal law to be implemented by the cantons, which would greatly facilitate further formal harmonization. They did not view material tax harmonization (common tax rates and exemptions) as an appropriate goal as this would eliminate scope for tax competition between cantons which has proved beneficial in keeping the overall Swiss tax burden low relative to its neighbors. The staff noted that some issues appear to fall into a gray area between these categories - for example, corporate taxation, which was shifted to proportional taxation of profits at the confederation level in 1997 but at cantonal level is taxed progressively on return on equity. International competitive pressures continue to affect Swiss taxation: notwithstanding various measures to alleviate the situation, the high level of taxation of securities transfers has led to a rising share of equity trading in Swiss shares taking place outside the country.

\section{The authorities shared staff concerns regarding long-run spending pressures} associated with population aging. Present plans for the first (public) pillar of Switzerland's three-pillar pension system are geared to stabilizing its finances ${ }^{20}$ as of 2010 through modest benefit reforms, budget transfers (financed by two further earmarked increases in VAT totaling 1.5 percent by 2006), and some increases in contribution rates. The authorities pointed to several advantages of using VAT for this purpose: first, the relatively low standard VAT rate (now 7.5 percent) would in any event need to rise in future to at least 15 percent if Switzerland were to realize its long-term goal of joining the EU; second, experience elsewhere in Europe pointed to the negative labor market consequences of reliance on increases in contribution rates; third, both old and young would contribute to the system's financing, avoiding objections from the young that could disrupt the solidarity concept underlying the system. The Ministry of Finance acknowledged that significant further action is needed to assure sustainability of the system's finances for the long haul. The Ministry was opposed, however, to solutions that would raise the overall tax burden and was seeking support for proposals focused on modifying inflation adjustments and lengthening contribution periods.

\section{The authorities are planning to overhaul Switzerland's system of}

intergovernmental fiscal relations (Box 3). This was a complex undertaking, given the number of parties and conflicting interests involved. Revised proposals are to be prepared by end-2000 on the basis of reactions to the April 1999 drafts, with a view to eventual implementation in 2004. The proposals focus on spending responsibilities and consequently would not affect the operation of the fiscal stabilizers on the revenue side.

\footnotetext{
${ }^{20}$ The scheme is operated on a PAYG basis with reserve funds. The object is to maintain the reserve at 70 percent of annual spending.
} 


\section{Box 3. Fiscal Relations Between the Confederation and Cantons}

The current proposal (Neuer Finanzousgleich, April 1999) envisages a substantial reallocation of strategic and operational responsibilities between the confederation and cantons, coupled with increased cantonal autonomy; encourages inter-cantonal cooperation; and rationalizes financial flows between different levels of government and creates incentives for reducing costs.

The envisaged reassignment of tasks would allow the confederation to concentrate its efforts on core responsibilities of nationwide significance (such as certain aspects of defense), and on setting strategic objectives for fiscal policy in the framework of multi-year plans. In most areas of the provision of public services (for instance, in social security and medical services), the cantons would obtain full responsibility for operational planning and implementation, and would become directly accountable for decisions in their competence. In addition, inter-cantonal cooperation would be required in areas where cantonal autonomy has led to duplication of efforts.

On the financing side, subventions from the confederation to cantons would, instead of automatically covering some share of total costs, become conditional on objectives and results, creating an incentive for reducing costs. At the same time, larger cantonal autonomy in decision-making would be matched by increased financial flexibility, as the share of resources at the discretion of the cantons would increase. 


\section{Structural Issues}

27. The authorities expressed satisfaction with the conclusion and ratification of the seven bilateral agreements with the EU in October 1999 (Box 4). These agreements met most of Switzerland's current integration needs and should help strengthen Swiss economic performance. The issue was, however, a dynamic one as the EU itself evolves over time. The government's ultimate goal remains EU membership, but it was expected that establishing the necessary public support would take a long time.

28. While recognizing that much remained to be done in product-market reforms, the authorities noted that recent initiatives were already bearing fruit. The Competition Commission has assumed an increasingly more active role in applying the 1996 Cartel Act and Domestic Market Act. The authorities intended to strengthen the authority of the Competition Commission to impose sanctions, noting that import cartels (for example, in automobiles) remained an important impediment to retail competition. In the utilities sector, liberalization and deregulation followed broadly similar EU initiatives, albeit at a slower pace. The opening up of telecommunications in 1998 had already generated a significant drop in fixed-line telephone charges and intense competition in mobile telephony. Rail transport had been partially liberalized by separating out the management of railway infrastructure and enacting rules ensuring non-discriminatory access to it. A six-year plan for opening up the electricity sector starting from 2001 is with parliament; ${ }^{21}$ electricity prices three times higher than in Sweden and almost double those in Germany put Swiss producers at a considerable disadvantage.

29. The staff encouraged action to reduce the protection and subsidization of agriculture, which is almost double the EU level. The 1999 agricultural reform program aims to increase reliance on market mechanisms and replace price subsidies with direct income payments, with annual budgetary support for agriculture during 2000-03 limited to its 1998 level. Tariff protection is being reduced in accordance with Switzerland's Uruguay Round commitments. The authorities expressed support for the opening of new WTO negotiations in 2000 on further liberalization of agriculture, services and public procurement, and a further strengthening of WTO rules, including the development of new rules on competition and investments.

${ }^{21}$ The proposal envisages a three-phase deregulation: in 2001, large firms (about 110 enterprises accounting for 12 percent of total electricity consumption) would be allowed to choose their supplier; smaller enterprises will be next in line, in 2004; and consumers last, in 2007. A small number of the 1,200 power providers and distributors are likely to remain in operation when liberalization will have been completed. 


\section{Box 4. Switzerland's Relations with the European Union}

In December 1992, the Swiss population rejected in a referendum, by a narrow margin, membership in the European Economic Area (EEA), leaving Switzerland as the only European Free Trade Association (EFTA) country remaining outside the EEA or the European Union (EU). In an effort to reduce the costs from remaining outside the EEA, the Swiss government entered into bilateral negotiations with the EU focusing on closer integration in seven areas: (i) participation in EU research programs; (ii) access to agricultural markets; (iii) public procurement; (iv) elimination of technical barriers to trade; (v) truck transit through Switzerland; (vi) air transportation; and (vii) free movement of labor.

The negotiations were long and difficult, mainly on account of the environmental implications of heavy truck transit through Switzerland. The agreements (together with legislation needed for their implementation) were ratified by the Swiss Parliament in October 1999. As they have to be ratified by all EU member states (and the EU parliament) and may also be subject to a referendum in Switzerland, the agreements are unlikely to enter into force before 2001 .

Looking beyond 2001, the Swiss Government envisages eventual full membership in the EU. As background information, the Government forwarded to Parliament in early 1999 an Integration Report, providing information about the political, economic, and financial implications of EU membership.

The report notes that full EU membership would clearly entail significant economic benefits for Switzerland and, moreover, give Switzerland a formal say in EU affairs. On the other hand, Switzerland would need to face three particularly difficult issues: (i) membership could constitute a significant challenge to the Swiss practice of direct democracy; (ii) direct budgetary transfers to the EU are expected to be considerable, as Switzerland is one of the richest countries in Europe; and (iii) Switzerland would be expected to give up its monctary autonomy. In this context, a number of observers have highlighted the potential cost of higher interest rates if the long-standing interest differential between Switzerland and the euro zone would disappear. Overall, a study by a Swiss research institute estimates a negative effect on GDP in the early years of membership which, however, is more than offset by the long-run beneficial effects: over a ten-year period, the bilateral agreements and EU entry raise annual average per capita GDP growth by 0.15 percent and 0.25 percent, respectively. ${ }^{1}$

${ }^{1}$ J. Bärlocher, B. Schips and P. Stadler, Makroökonomische Auswirkungen eines EU-Beitrittes der Schweiz, ETH Zürich, 1999. 
30. Despite recent misadventures, the internationally active Swiss banks remain well-positioned, but the domestic banking sector faces significant challenges. ${ }^{22}$ This sector is dominated by a few large banks, including the state-owned cantonal banks, and is less exposed to competitive pressures than the international banks. The staff expressed concerns about the resulting lack of dynamism in the domestic sector and the potential distortions arising from the state guarantees of the cantonal banks' liabilities and other privileges including a lower capital adequacy requirement for fully guaranteed banks. The state guarantees would allow the cantonal banks to increase their risk taking at the taxpayers' expense, which in particular could be a matter of concern if the lending margins were to come under increased pressure (e.g., as a result of foreign entry). In addition, the location in Switzerland of two of the world's largest international banks poses significant challenges for supervisors.

31. Although sharing these concerns to some extent, the authorities explained that an important step had been taken toward reducing the privileges of the cantonal banks: the amendment of the Banking Act enacted in October 1999 removed from the cantons the obligation to guarantee the cantonal banks' operations. In addition, banking supervision had been strengthened in 1999: the cantonal banks are now to be supervised by the Federal Banking Commission (FBC); a special unit responsible for supervising the large banking groups was fully operative in July; greater flexibility in budgeting operational costs had been introduced; and steps had been taken to facilitate onsite inspection by foreign supervisors of subsidiaries operating in Switzerland. Moreover, a wide-ranging review of the current system of financial supervision had been initiated, with a mandate to look into the treatment of unregulated providers of financial services, the increasing overlap between banking and insurance, and reform of the deposit insurance system. Finally, the authorities noted that Swiss banks were well capitalized: the consolidated capital adequacy ratio of the internationally active large banking groups was 14.8 percent in June (excluding international subsidiaries, the capital ratio of the Swiss banking system as a whole was 11.3 percent in December 1998).

32. The authorities have stepped up their effort to combat money laundering. The April 1998 Money Laundering Act requires anyone who professionally manages assets belonging to third parties to show due diligence and formally report suspicious transactions to the Money Laundering Reporting Office. The government's proposals to ratify the OECD International Convention on Bribery and implement the associated legislation are under consideration in parliament.

33. The low unemployment rate underscores the flexibility of the Swiss labor market relative to its European neighbors. To promote greater efficiency in administering unemployment insurance, starting in 2001 the authorities plan to restructure the funding of the

\footnotetext{
${ }^{22}$ The challenges facing the banking sector are reviewed in Chapter $I$ of the accompanying Selected Issues paper.
} 
regional job placement offices. Cantons exhibiting above average success in, say, reintegrating unemployed in the labor market or avoiding long-term unemployment would be compensated by more than the actual cost of running the offices. A comprehensive assessment of the 1996-97 reforms is expected in early 2000 and will be input for the next revision of unemployment insurance scheduled for 2003.

\section{E. Other Issues}

34. The authorities were urged to strengthen ongoing efforts to improve the quality and coverage of economic statistics. Quarterly data on capital flows and monthly data on the composition of foreign exchange reserves started to be published in 1999. The new Statistical Program for 1999-2003 included, inter alia, the release in 2000 of sectoral GDP data for 1990-97; the revision of the CPI in 2000; and preparations for the transition to ESA95 (Appendix III). The staff emphasized that the adoption of a monetary framework incorporating inflation forecasts placed an added premium on improving data in areas such as the labor market.

35. Official development assistance (ODA) is set to remain at about 0.3 percent of GDP, below the 0.4 percent objective set by the Federal Council in 1994 . The authorities stressed that they attached high political priority to this objective and intended to raise ODA when the fiscal position permitted. They also noted that Switzerland provided sizeable international assistance in forms that were not classified as ODA, such as humanitarian contributions in connection with the Kosovo crisis.

\section{STAFF APPRAISAL}

36. Switzerland's economy is on a positive track, thanks to an improving external environment and sound macroeconomic policies. The main tasks looking forward are to maintain noninflationary economic recovery and to take advantage of these favorable conditions to strengthen long-term performance.

37. In light of the envisaged upswing, the current stance of macroeconomic policies, taking account both of this year's planned fiscal consolidation and the SNB's actions to raise short-term interest rates in September and January, provides a degree of insurance against upside inflation risks. At the same time, the lags between policy action and inflation call for vigilance to assure medium-term price stability, and particular attention will need to be paid in the period ahead to indications of possible inflationary pressure. All in all, while some additional firming of monetary conditions is warranted in due course as the upswing matures, further policy tightening does not appear needed for the time being.

38. With the SNB's previous base money target having lost much of its information and thus operational value, the new policy framework announced in late 1999 provides welcome clarification of the authorities' intentions with regard to the conduct of monetary policy. In line with earlier staff recommendations, the new framework focuses on the goal of medium-term price stability, with policy decisions guided by an inflation forecast 
based on relevant indicators. It will be desirable, especially in light of the relatively wide band chosen for the reference interest rate, to communicate changes in the policy stance clearly to the public in a timely fashion. Similarly, a transparent presentation of the analytic framework used to generate the forecasts would strengthen communication with markets and enhance policy credibility.

39. Retaining monetary autonomy has allowed Switzerland to enjoy the benefits of relatively low interest rates, while the Swiss franc has exhibited a high degree of exchange rate stability vis-a-vis the euro. The large external current account surplus suggests scope for Switzerland's real effective exchange rate to rise over the medium term. While monetary policy is appropriately geared to domestic objectives, some nominal effective appreciation of the Swiss franc, in the wake of monetary tightening as the upswing matures and to assure price stability, would thus not be cause for concern.

40. Recent fiscal developments have been positive. Policies are on track to observe the constitutional limit on the budget deficit of the Confederation in 2000 and to arrest the rise in the debt/GDP ratio, and the objective of balance in 2001 can be met with the introduction of modest additional expenditure savings in the 2001 budget. Continued commitment to this objective is important for confidence and the broad economic climate, and it is essential therefore to resist pressures to relax fiscal policies.

41. For the fiscal policy framework after 2001, the proposed goal of balancing the Confederation budget over the cycle would appropriately maintain the debt/GDP ratio on a declining trend. A key consideration in designing the framework will be ensuring that the automatic stabilizers $\longrightarrow$ which should become more effective once tax collections in most cantons shift to a current-year basis, as envisaged by 2001 -are allowed to operate. The intention to establish medium-term expenditure ceilings linked to the expected trend rate of economic growth, and to allow tax revenues and the deficit to fluctuate with the cycle - an approach that has had success elsewhere in Europe-is therefore welcome.

42. The tax policy agenda is considerable, given the complications and efficiency costs of the current system. The emphasis on achieving formal tax harmonization and on developing new legal mechanisms for facilitating the harmonization process is appropriate. While mandatory material harmonization of tax rates across cantons is not needed and would reduce beneficial tax competition, it would be worthwhile to encourage cantons to consider shifting their corporate income tax systems to a system of proportional taxation of profits. As regards the securities transfer tax, the rising share of transactions in Swiss shares being carried out on non-Swiss exchanges suggests that further initiatives will likely be needed on this issue.

\section{Switzerland's multi-pillar approach to social insurance has important} advantages over single-pillar PAYG schemes prevalent in some other European countries. Nevertheless, the state pillar of the Swiss system will face significant demographic pressures in the coming decades notably after 2010 , the current policy planning horizon. Through early action to address these long-term pressures, the scope for choice among the 
various options would be maximized. In this context, the intention to focus on benefit formulae and contribution periods is appropriate.

\section{The $\mathbf{E U}$ is a key element of the external changes and challenges facing}

Switzerland. The launch of the euro is already a major shift, with implications for the Swiss franc, the competitive environment for Swiss exporters, and the financial system. The ongoing dynâmic process of European integration will continue to affect Switzerland regardless of any future decision on possible EU accession. In this context, the conclusion of the bilateral agreements with the EU is a major positive step; once in effect, these agreements should yield important long-term growth benefits through increased trade and investment. With Switzerland lagging the EU in aspects of product market reform, securing these benefits will require exceeding the pace of future $\mathrm{EU}$ reform.

\section{Against this background, the need is to build on recent progress and deepen} reform of the "sheltered sectors." The recent changes in agricultural support policies are a start, but overall support levels remain considerably above even those in the EU. The more proactive approach to competition policy, and proposals to reinforce further the powers of the Competition Commission, are welcome, but monopolistic and oligopolistic practices in importing and domestic activity, which appear to be a factor in the relatively high level of Swiss consumer prices, should be tackled with vigor. As regards utilities, recent reforms of telecommunications, rail and postal services are steps in the right direction, and follow-up actions are desirable. In the electricity sector where reforms are yet to begin and are scheduled to take several years, acceleration of the timetable would be welcome.

\section{While the Swiss financial sector appears likely to remain a major contributor to} the Swiss economy, external and internal competitive forces and technological advances are all sources of pressures for change. These pressures are particularly strong for the cantonal banks, where the roles of guarantees, public ownership, and noneconomic mandates will come increasingly into question as possibly inhibiting new entry and as posing risks for cantonal taxpayers. In this regard, the new Banking Act, with its greater flexibility on the role of guarantees and in extending the supervisory mandate of the Federal Banking Commission to these banks is a step in the right direction. It would be desirable to put all banks on an equal footing by a reduction of the public guarantees and other privileges extended to the cantonal banks. As the role of public guarantees evolves, supervisors will need to remain particularly vigilant and ensure that capital levels in the cantonal banks are in line with their risk-exposure and risk-management capabilities. As to the supervision of the large banks, international cooperation is essential and the recent step to facilitate on-site inspection in Switzerland by foreign supervisors is thus welcome. The ongoing review of the structure of financial supervision, deposit insurance, and bank insolvency rules is timely, as are the recent legal and institutional changes designed to combat money laundering.

47. While Switzerland's humanitarian contributions in connection with the Kosovo conflict are recognized, an increase in official development assistance to the national target of 0.4 percent of GDP is encouraged. 
48. While data provided to the Fund are generally adequate for surveillance, there are deficiencies in some areas. Planned improvements in wage and government finance statistics need to be implemented on an urgent basis to strengthen the basis for sound economic management in the context of the SNB's new monetary framework.

49. It is recommended that the next Article IV consultation with Switzerland be held on the standard twelve-month cycle. 


\section{Switzerland: Basic Data}

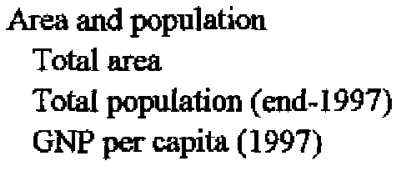

41,293 square kilometers

7.I million

$\$ \mathbf{3 8 , 3 0 1}$

\begin{tabular}{|c|c|c|c|c|c|c|c|}
\hline & 1997 & 1998 & 1999 & $20001 /$ & $2001 i$ & 20021 & $20031 /$ \\
\hline & \multicolumn{7}{|c|}{ (Percentage changes at 1990 prices) } \\
\hline \multicolumn{8}{|l|}{ Demand and supply } \\
\hline Private consumption & 1.3 & 2.3 & 2.0 & 1.9 & 1.8 & 1.7 & 1.6 \\
\hline Public consumption & 0.6 & -0.2 & 0.3 & 0.0 & -0.1 & 0.0 & 0.0 \\
\hline Gross fixed investment & 1.5 & 4.4 & 2.4 & 4.7 & 4.5 & 3.8 & 3.3 \\
\hline Construction & -1.5 & 0.4 & 1.3 & 4.9 & 4.5 & 3.0 & 3.0 \\
\hline Machinery and equipment & 4.9 & 8.6 & 3.5 & 4.4 & 4.5 & 4.5 & 3.5 \\
\hline Final domestic demand & 1.2 & 2.4 & 1.9 & 2.3 & 2.2 & 2.0 & 1.8 \\
\hline Inventory accumulation 2 / & 0.1 & 1.7 & 0.1 & -0.9 & -0.4 & -0.1 & 0.0 \\
\hline Total domestic demand & 1.3 & 4.1 & 1.9 & 1.4 & 1.9 & 1.9 & 1.8 \\
\hline Exports of goods and nonfactor services & 9.0 & 4.6 & 3.7 & 7.2 & 5.6 & 5.1 & 5.1 \\
\hline Imports of goods and nonfactor services & 8.1 & 9.4 & 4.9 & 5.7 & 5.6 & 5.6 & 5.5 \\
\hline GDP & 1.7 & 2.1 & 1.4 & 2.0 & 1.8 & 1.6 & 1.5 \\
\hline \multirow[t]{2}{*}{ GNP } & 3.6 & 1.6 & 4.3 & -0.6 & 1.9 & 1.7 & 1.6 \\
\hline & \multicolumn{7}{|c|}{ (In billions of Sw F, at current prices) } \\
\hline \multirow[t]{2}{*}{ GDP } & 371.6 & 380.0 & 388.7 & 401.9 & 415.3 & 427,0 & 437.9 \\
\hline & \multicolumn{7}{|c|}{ (In milhions, unless otherwise indicated) } \\
\hline \multicolumn{8}{|l|}{ Employment and unemployment } \\
\hline Employment & 3,803 & 3,850 & 3,891 & 3,921 & 3,944 & 3,966 & 3,987 \\
\hline (Percent change) & -0.3 & 1.2 & 1.1 & 0.8 & 0.6 & 0.5 & 0.5 \\
\hline Unemployed (registered) & 0.19 & 0.14 & 0.10 & 0.09 & 0.09 & 0.08 & 0.08 \\
\hline \multirow[t]{2}{*}{ Unemployment rate (in percent) } & 5.2 & 3.9 & 2.7 & 2.3 & 2.2 & 2.2 & 2.1 \\
\hline & \multicolumn{7}{|c|}{ (Percentage changes, unless otherwise indicated) } \\
\hline \multicolumn{8}{|l|}{ Prices and incomes } \\
\hline GDP deflator & -0.1 & 0.2 & 0.9 & 1.4 & 1.5 & 1.3 & 1.0 \\
\hline Consumer price index & 0.5 & 0.1 & 0.8 & 1.3 & 1.5 & 1.3 & 1.3 \\
\hline Nominal wage growth $3 /$ & 0.5 & 0.7 & 1.0 & 2.2 & 2.0 & 1.5 & 1.5 \\
\hline Unit labor costs (total economy) & -1.4 & -0.1 & 0.7 & 1.0 & 0.8 & 0.5 & 0.5 \\
\hline Real disposable income & 2.3 & 1.7 & 3.7 & 0.3 & 2.2 & 1.8 & 1.7 \\
\hline \multirow[t]{2}{*}{ Personal savings ratio (in percent) } & 10.0 & 9.4 & 10.9 & 9.5 & 9.9 & 9.9 & 10.0 \\
\hline & \multicolumn{7}{|c|}{ (In percent of GDP) } \\
\hline \multicolumn{8}{|l|}{ Public finances } \\
\hline Central government financial balance 4/ & -1.5 & -0.7 & -0.9 & -0.6 & -0.6 & -0.3 & 0.1 \\
\hline Gross debt & 25.1 & 27.7 & 28.0 & 27.7 & 27.4 & 27.0 & 26.2 \\
\hline \multicolumn{8}{|l|}{ General government } \\
\hline Financial balance 4/ & -2.4 & -1.1 & -1.4 & -1.2 & -1.4 & -0.9 & -0.5 \\
\hline Structural balance & -1.3 & -0.4 & -1.1 & -1.0 & -1.3 & -1.0 & -0.7 \\
\hline Gross debt & 51.5 & 53.8 & 54.0 & 53.4 & 52.8 & 52.3 & 51.4 \\
\hline Expenditure & 39.4 & 39.3 & 39.1 & 38.4 & 38.1 & 38.1 & 38.3 \\
\hline
\end{tabular}

1/ Staff projections.

2/ Change as percent of previous year's GDP.

3/Nominal wage growth per employee.

4/ Excluding cash supplus of civil service pension fund as revenue; from 1997 onward, including railway loans as expenditure. 
Switzerland: Basic Data (concluded)

\begin{tabular}{|c|c|c|c|c|c|c|c|}
\hline & 1997 & 1998 & 1999 & $20001 /$ & 20011 & 20021 & $20031 /$ \\
\hline & \multicolumn{7}{|c|}{ (In billions of Sw F, unless otherwise indicated) } \\
\hline \multicolumn{8}{|l|}{ Balance of payments } \\
\hline Trade batance & -0.5 & -2.2 & 0.1 & -0.7 & -0.4 & -1.5 & -2.1 \\
\hline Service balance & 18.9 & 19.0 & 20.5 & 21.9 & 22.6 & 23.0 & 23.2 \\
\hline Factor income balance & 24.0 & 23.3 & 36.0 & 25.5 & 26.5 & 27.5 & 28.5 \\
\hline Net private transfers & -3.0 & -3.0 & -3.5 & -4.1 & -4.8 & -5.2 & -5.6 \\
\hline Net official transfers & -1.9 & -2.4 & -2.4 & -2.4 & -2.4 & -2.4 & -2.4 \\
\hline Current account & 37.5 & 34.7 & 50.8 & 40.1 & 41.5 & 41.4 & 41.6 \\
\hline (In percent of GDP) & 10.1 & 9.1 & 13.1 & 10.0 & 10.0 & 9.7 & 9.5 \\
\hline Foreign direct investment & -18.8 & -13.7 & -15.0 & -14.5 & -14.5 & -14.5 & -14.5 \\
\hline Outward & -26.1 & -20.6 & -25.0 & -22.0 & -22.0 & -22.0 & -22.0 \\
\hline Inward & 7.3 & 6.9 & 10.0 & 7.5 & 7.5 & 7.5 & 7.5 \\
\hline Portfolio investment & -17.3 & -6.6 & -60.0 & -25.4 & -21.8 & -21.7 & -21.9 \\
\hline Outward & -30.4 & -21.5 & -70.0 & -30.0 & -30.0 & -30.0 & -30.0 \\
\hline Inward & 13.1 & 14.9 & 10.0 & 4.6 & 8.2 & 8.3 & 8.1 \\
\hline Banking sector, net & 0.5 & -17.0 & 30.0 & -5.0 & -10.0 & -10.0 & -10.0 \\
\hline \multicolumn{8}{|l|}{ Memorandum items: } \\
\hline Net investment income & 30.5 & 29.8 & 42.5 & 32.0 & 33.0 & 34.0 & 35.0 \\
\hline (In percent of GDP) & 8.2 & 7.8 & 10.9 & 8.0 & 7.9 & 8.0 & 8.0 \\
\hline Net external assets & 449.1 & 486.6 & 533.2 & 573.1 & 614.4 & 655.7 & 697.0 \\
\hline (In percent of GDP) & 120.9 & 128.0 & 137.2 & 142.6 & 148.0 & 153.6 & 159.2 \\
\hline Official reserves (billions of US\$, end period) $2 /$ & 39.0 & 41.2 & 34.6 & $\ldots$ & $\ldots$ & $\ldots$ & $\ldots$ \\
\hline Reserve cover (months of imports of GNFS) & 5.2 & 4.9 & 4.4 & $\cdots$ & $\ldots$ & $\cdots$ & $\cdots$ \\
\hline & \multicolumn{7}{|c|}{ (Percentage changes in annual averages) } \\
\hline \multicolumn{8}{|l|}{ Monetary and credit data 3 / } \\
\hline Monetary base & 4.8 & 3.0 & 1.9 & $\ldots$ & $\ldots$ & $\ldots$ & $\ldots$ \\
\hline Money (Ml) & 10.0 & 7.7 & 8.7 & $\cdots$ & $\ldots$ & $\ldots$ & $\ldots$ \\
\hline Broad money (M3) & 4.8 & 1.0 & 1.6 & $\ldots$ & $\ldots$ & $\ldots$ & $\ldots$ \\
\hline Domestic credit & 1.7 & 0.8 & 1.2 & $\ldots$ & $\ldots$ & $\ldots$ & $\ldots$ \\
\hline \multicolumn{8}{|c|}{ (Period averages in percent) } \\
\hline \multicolumn{8}{|l|}{ Interest rates } \\
\hline Three-month euro rate & 1.6 & 1.5 & 1.4 & $\ldots$ & $\ldots$ & $\ldots$ & $\ldots$ \\
\hline \multirow[t]{2}{*}{ Yield on government bonds } & 3.5 & 2.9 & 2.9 & $\ldots$ & $\ldots$ & $\cdots$ & $\ldots$ \\
\hline & \multicolumn{7}{|c|}{ (Levels) } \\
\hline \multicolumn{8}{|l|}{ Exchange rates } \\
\hline Sw F per US\$ (end of period) & 1.44 & 1.36 & 1.54 & ... & $\ldots$ & $\ldots$ & $\ldots$ \\
\hline Sw F per US\$ (annual average) & 1.45 & 1.45 & 1.50 & $\ldots$ & $\cdots$ & $\cdots$ & $\cdots$ \\
\hline Sw F per euro (annual average) & 1.64 & 1.61 & 1.60 & $\ldots$ & $\ldots$ & $\ldots$ & $\ldots$ \\
\hline Nominal effective rate $(1990=100)$ & 104.3 & 107.0 & 105.3 & $\ldots$ & $\ldots$ & $\ldots$ & $\ldots$ \\
\hline Real effective rate $(1990=100) 4 /$ & 100.9 & 102.1 & 100.4 & $\ldots$ & $\ldots$ & $\ldots$ & $\ldots$ \\
\hline
\end{tabular}

Source: International Monetary Fund, World Economic Outlook database; Swiss National Bank; Swiss Institute for Business Cycle Research.

1/ Staff projections unless otherwise noted.

$2 /$ For 1999 , end-November data.

3/For 1999, first ten months compared with same period a year ago.

4/ Based on consumer prices. 
Switzerland: Fund Relations

(As of December 31, 1999)

I. Membership Status: Joined 5/29/92; Switzerland has accepted the obligations of Article VIII, Sections 2, 3 and 4.

II. General Resources Account:

$\begin{array}{rr}\text { SDR Million } & \text { \% Quota } \\ & \\ 3,458.50 & 100.0 \\ 2,240.42 & 64.8 \\ 1,218.12 & 35.2 \\ -27.00 & -\end{array}$

III. SDR Department:

SDR Million \% Allocation

Holdings

344.72

IV. Outstanding Purchases and Loans: None

V. Financial Arrangements: None

VI. Projected Obligations to Fund: None

VII. Exchange Rate Arrangement:

The Swiss National Bank does not maintain margins in respect of exchange transactions. However, the Swiss National Bank has intervened when warranted by the circumstances. Switzerland's exchange system is free of restrictions on the making of payments and transfers for current international transactions. However, Switzerland continues to apply exchange restrictions vis-à-vis Iraq (since August 1990).

VIII. Article IV Consultations:

Switzerland is on the standard 12-month Article IV consultation cycle.

IX. Technical Assistance: None

X. Resident Representatives: None 


\section{Switzerland: Statistical Appendix}

Switzerland publishes timely economic statistics and posts most of the data and the underlying documentation on the internet. Switzerland was also among the initial subscribers to the Fund's Special Data Dissemination Standard (SDDS) and its metadata are currently posted on the Dissemination Standards Bulletin Board. However, a number of statistical gaps and deficiencies remain to be addressed: data on value added and capital formation by sector become available intermittently in nominal terms only and with a lag of several years; employment statistics are derived from disparate sources and are of variable quality; wage statistics are based on a narrow coverage and monthly data are not available; statistics on fiscal transactions are incomplete, for example internationally comparable general government data on an accrual basis are not available, and the provision of fiscal data is subject to considerable delays; moreover, there are no flow-of-funds data.

To address these problems, the authorities have taken or intend to take the following steps:

- The Swiss National Bank (SNB) begun publishing in September 1999 quarterly capital and financial account statistics, fulfilling one of the requirements of the SDDS.

- In July 1999, the SNB started publishing monthly data on the composition of its foreign exchange reserves in line with recommendations by the Committee on the Global Financial System.

- The SNB introduced a new survey of cross-border portfolio investment flows, which improves the measurement of portfolio investment flows in the balance of payments.

- The Ministry of Finance started releasing in 1999 monthly data on federal government expenditure and revenue (both on a cash basis) and quarterly general government debt.

The Statistical Program for 1999-2003 of the Federal Statistical Office (FSO) includes:

- The introduction of a revised CPI in 2000.

- The adoption by 2001 of the 1995 European System of Integrated Economic Accounts (ESA). The 1979 ESA was adopted in mid-1997.

- The publication in 2000 of sectoral value added data covering the period 1990-97.

- In the area of labor market statistics, the harmonization of employment statistics by 2002 and improved wage statistics by 2001 (current wage statistics are based on accident insurance information for blue collar workers).

- The completion of conceptual work on financial accounts (a joint project involving the FSO and the SNB) by 2001.

- A Maastricht-compatible accounting framework for the public finances by 2001. 
Switzerland: Core Statistical Indicators as of December 31, 1999

\begin{tabular}{|c|c|c|c|c|c|c|c|c|c|c|c|c|}
\hline & $\begin{array}{c}\text { Exchange } \\
\text { Rates }\end{array}$ & $\begin{array}{c}\text { Foreign } \\
\text { Reserves }\end{array}$ & $\begin{array}{c}\text { Central } \\
\text { Bank } \\
\text { Balance } \\
\text { Sheet } \\
\end{array}$ & $\begin{array}{c}\text { Reserve/ } \\
\text { Base } \\
\text { money } \\
\end{array}$ & $\begin{array}{l}\text { Broad } \\
\text { Money } \\
\end{array}$ & $\begin{array}{c}\text { Interest } \\
\text { Rates } \\
\end{array}$ & $\begin{array}{c}\text { Consumer } \\
\text { Price } \\
\text { Index } \\
\end{array}$ & $\begin{array}{l}\text { Exports/ } \\
\text { Imports } \\
\end{array}$ & $\begin{array}{l}\text { Current } \\
\text { Account } \\
\text { Balance } \\
\end{array}$ & $\begin{array}{c}\text { Overall } \\
\text { Govern- } \\
\text { ment } \\
\text { Balance } \\
\end{array}$ & $\begin{array}{l}\text { GDP/ } \\
\text { GNP }\end{array}$ & $\begin{array}{c}\text { Extennal } \\
\text { Debt }\end{array}$ \\
\hline $\begin{array}{l}\text { Date of Latest } \\
\text { Observation }\end{array}$ & $12 / 30 / 99$ & $12 / 30 / 99$ & $12 / 30 / 99$ & $11 / 30 / 99$ & $11 / 30 / 99$ & $12 / 30 / 99$ & $12 / 99$ & $11 / 99$ & Q3/99 & 1998 & Q3/99 & 1998 \\
\hline Date Received & $12 / 30 / 99$ & $12 / 30 / 99$ & $12 / 30 / 99$ & $12 / 25 / 99$ & $12 / 25 / 99$ & $12 / 30 / 99$ & $12 / 30 / 99$ & $12 / 99$ & $12 / 9 / 99$ & $10 / 99$ & $12 / 9 / 99$ & $12 / 99$ \\
\hline $\begin{array}{l}\text { Frequency of } \\
\text { Data }\end{array}$ & Daily & $\begin{array}{c}\text { Each } 10^{\text {th }} \\
\text { day }\end{array}$ & $\begin{array}{c}\text { Each } 10^{\text {th }} \\
\text { day }\end{array}$ & Monthly & Monthly & Daily & Monthly & Monthly & Quarterly & Annual & Quarterly & Annual \\
\hline $\begin{array}{l}\text { Frequency of } \\
\text { Reporting }\end{array}$ & Daily & Monthly & Monthly & Monthly & Monthly & Daily & Monthly & Monthly & Quarterly & Annual & Quarterly & Annual \\
\hline Source of Update & TRE & SNB & SNB & SNB & SNB & TRE/RES & BFS & $\begin{array}{c}\text { SNB } \\
\text { KOF tape }\end{array}$ & $\begin{array}{c}\text { SNB } \\
\text { KOF tape }\end{array}$ & MoF & $\begin{array}{l}\text { BFK } \\
\text { BFS }\end{array}$ & SNB \\
\hline $\begin{array}{l}\text { Mode of } \\
\text { Reporting }\end{array}$ & Electronic & Mail & Mail & $\begin{array}{c}\text { Mail } \\
\text { Electronic }\end{array}$ & $\begin{array}{c}\text { Mail } \\
\text { Electronic }\end{array}$ & Electronic & Electronic & $\begin{array}{l}\text { KOF tape } \\
\text { Electronic }\end{array}$ & $\begin{array}{c}\text { Mail } \\
\text { KOF tape }\end{array}$ & Mission & Electronic & Mail \\
\hline Confidentiality & None & None & None & None & None & None & None & None & None & None & None & None \\
\hline $\begin{array}{l}\text { Frequency of } \\
\text { Publication }\end{array}$ & Daily & $\begin{array}{c}\text { Each } 10^{\text {th }} \\
\text { day }\end{array}$ & $\begin{array}{c}\text { Each } 10^{\text {th }} \\
\text { day }\end{array}$ & Monthly & Monthly & Daily & Monthly & Monthly & Quarterly & Annual & Quarterly & Monthly \\
\hline
\end{tabular}

BFS $=$ Federal Statiscal Office

SNB $=$ Swiss National Bank

KOF $=$ Swiss Institute for Business Cycle Research

MoF $=$ Federal Ministry of Finance

BFK = Federal Office for Economic Policy 


\title{
INTERNATIONAL MONETARY FUND
}

\author{
SWITZERLAND \\ Staff Report for the 1999 Article IV Consultation \\ Supplementary Information
}

Prepared by the European I Department

Approved by Alessandro Leipold and G. Russell Kincaid

February 11,2000

1. This statement provides information on economic and financial developments that has become available since the issuance of the staff report (SM/00/13, 1/24/00). This information does not alter the thrust of the staff appraisal.

2. Recent indicators confirm that the recovery has been gathering momentum, in line with projections in the staff report. The composite leading economic indicator rose for the thirteenth consecutive month in December 1999. Merchandise exports increased strongly at end-year, and consumer confidence has climbed to an 11 -year high. Unemployment increased slightly to 2.6 percent in January 2000 , reflecting seasonal factors.

3. Headline CPI inflation declined by 0.1 percentage point in January to 1.6 percent. Excluding the effect of energy prices, CPI inflation remained unchanged at 0.8 percent. Headline inflation is projected by staff to decline somewhat further in the coming months as the effects of the VAT increase in early 1999 and the sharp rise in energy prices fade out from the calculation, outweighing effects of the recent weakening in the nominal exchange rate.

4. As noted in the staff report, on January 20th the Swiss National Bank (SNB) announced that it would target the three-month LIBOR rate in the upper-rather than (as

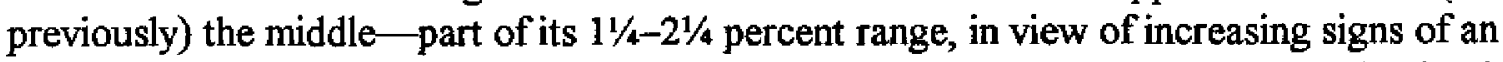
improved cyclical position. More recently, following the February 3 interest rate hike by the ECB, the SNB raised the target range by half a percentage point to $13 / 4-23 / 4$ percent and announced that it would keep the three-month LIBOR at the middle of the new range. The SNB announced that this move was aimed at counteracting inflation risks stemming from relaxation of monetary conditions associated with the weakening of the Swiss franc in nominal effective terms. All in all, the three-month LIBOR has increased from $1 \frac{1}{4}$ percent in midSeptember 1999 (before the SNB acted to raise interest rates) to $2 \frac{1 / 4}{4}$ percent in mid-February 2000 , with $1 / 4$ percentage point coming since the February 3 announcement (Figure 1). With the nominal effective exchange rate having depreciated by $21 / 4$ percent since September (Figure 2), the staff estimates that monetary conditions have remained broadly unchanged (Figure 3). As indicated in the report, monetary conditions are appropriately supportive for this stage of the cycle although some firming will be warranted in due course as remaining slack is absorbed. 
Figure 1. Switzerland: Three-Month Swiss Franc LIBOR

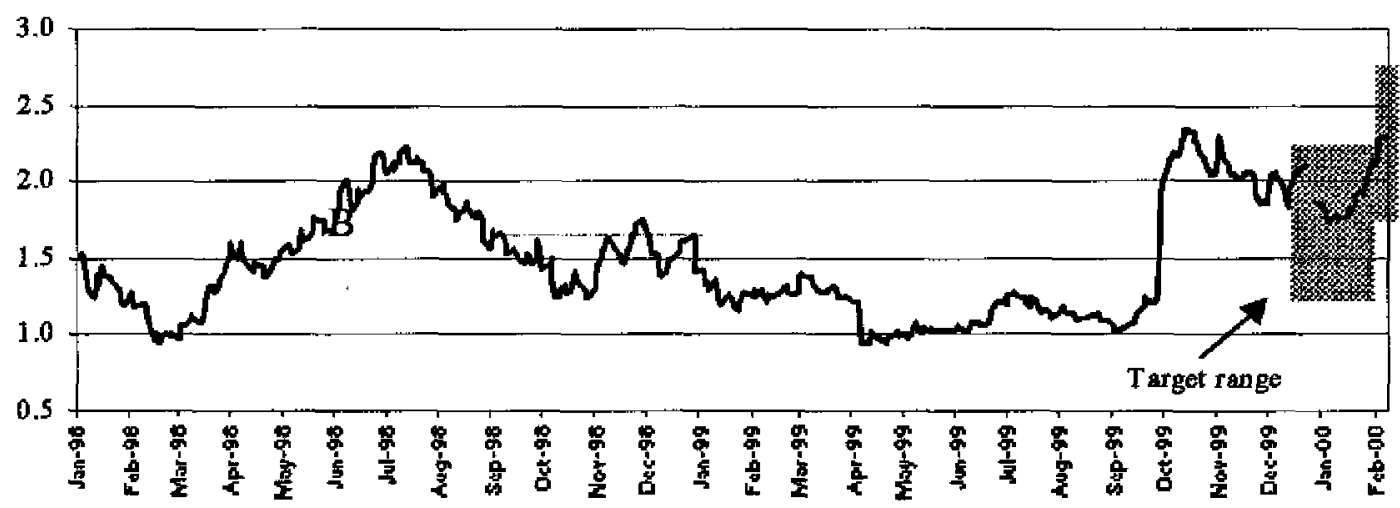

Figure 2. Switzerland: Exchange Rate Developments

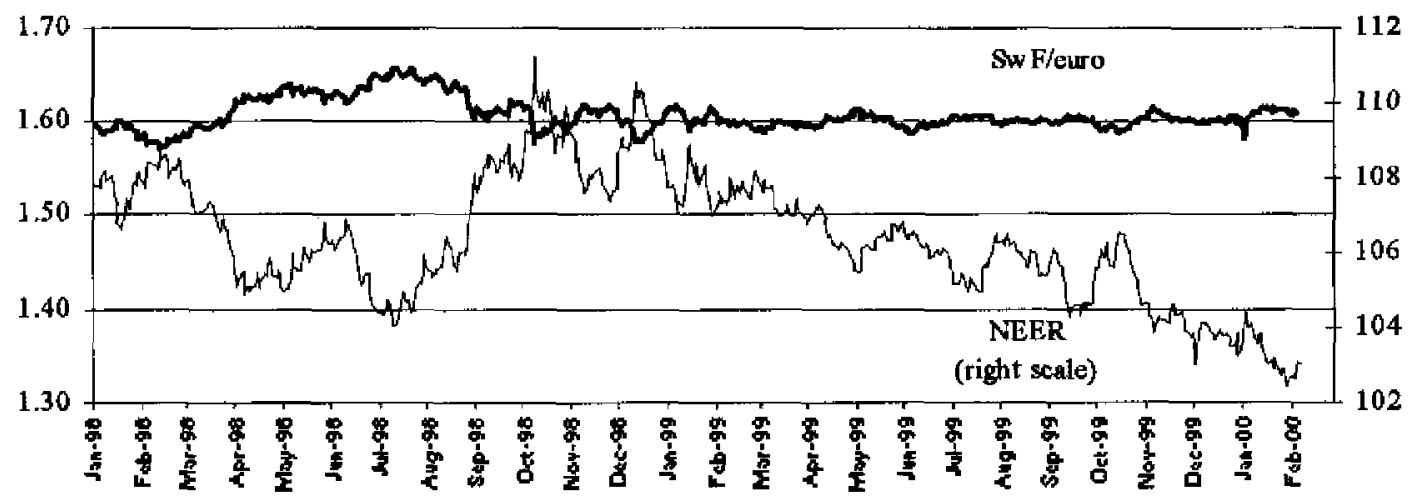

Figure 3. Switzerland: Monetary Conditions Index

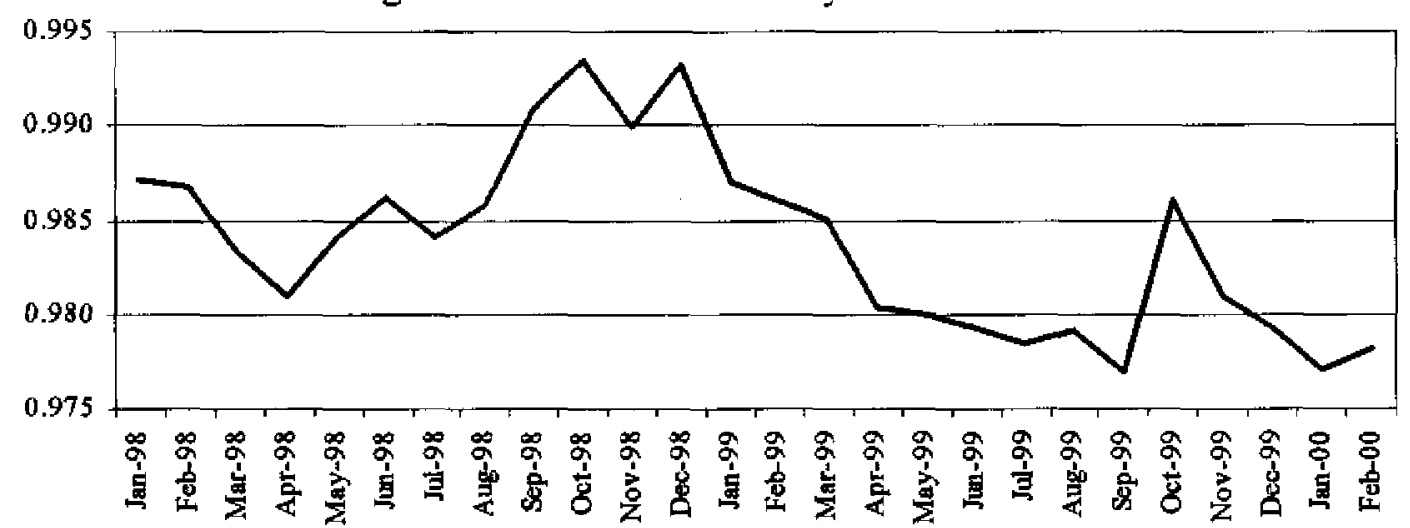

1/ Based on nominal interest and exchange rates with weights proportional to 2.5 and 1, respectively; 1994=1. 
Public Information Notice (PIN) No. 00/14 FOR IMMEDIATE RELEASE

March 2, 2000
International Monetary Fund $70019^{\text {th }}$ Street, NW

Washington, D. C. 20431 USA

\section{IMF Concludes Article IV Consultation with Switzerland}

On February 14, 2000, the Executive Board concluded the Article IV consultation with Switzerland. ${ }^{1}$

\section{Background}

The upswing of the Swiss economy regained momentum after weakening temporarily in the wake of the emerging markets crisis. The slump in external demand reduced GDP growth from a peak rate of 3.7 percent in mid-1997 to 1 percent for the period through mid-1999. In the third quarter of 1999 , however, activity picked up as exports recovered and domestic demand strengthened, with GDP growth estimated at 1.4 percent for the year.

Unemployment has declined rapidly to below $2 \frac{1}{2}$ percent from its 1997 peak of over 5 percent. In its early stages, the decline was attributable mainly to increased participation in active labor market programs (made a condition for benefit eligibility) whereas the more recent decline is associated with the upswing in activity and related increase in labor demand.

After hovering around zero throughout 1998, headline CPI inflation rose to 1.6 percent in January 2000 . This reflects primarily a 1 percentage point increase in the VAT rate in January 1999 , the sharp rebound of oil prices, the weakening of the effective exchange rate, and higher rents associated with improving housing market conditions. Excluding the

\footnotetext{
${ }^{1}$ Under Article IV of the IMF's Articles of Agreement, the IMF holds bilateral discussions with members, usually every year. A staff team visits the country, collects economic and financial information, and discusses with officials the country's economic developments and policies. On return to headquarters, the staff prepares a report, which forms the basis for discussion by the Executive Board. At the conclusion of the discussion, the Managing Director, as Chairman of the Board, summarizes the views of Executive Directors, and this summary is transmitted to the country's authorities. In this PIN, the main features of the Board's discussion are described.
} 
temporary effects of indirect taxes and oil price increases, inflation is estimated to have risen over the same period from $1 / 4$ percent to about $3 / 4$ percent.

The longstanding external current account surplus was above 9 percent of GDP in 1998 and is estimated to have risen further in 1999. The record-high current account surpluses of the past few years are related primarily to the high net investment income ( 8 percent of GDP in 199799) on Switzerland's large net foreign asset position (130 percent of GDP).

Monetary policy has shifted from an accommodative to a more neutral posture. Amidst faltering economic activity and deflation risks, the SNB maintained for most of 1999 an accommodative stance. In April it reduced the discount rate to 0.5 percent, which pushed the 3-month LIBOR to around 1 percent in the ensuing months; meanwhile, the monetary conditions index fell in September to its lowest level since 1997. But with increasing indications of strengthening economic activity, the edging up of inflation, and the weakening of the nominal effective exchange rate, the SNB let interest rates increase in steps since late September bringing the 3-month LIBOR to $2 \frac{1}{4}$ percent by mid-February 2000 . In December 1999, the SNB announced a new monetary policy framework which is geared toward price stability (defined as CPI inflation of less than 2 percent) and uses the 3-month LIBOR as the operating target.

The Swiss franc has shadowed the euro closely since January 1999, fluctuating narrowly around 1.6 Sw Fleuro. To a large extent this reflects the similar cyclical positions of the Swiss and euro area economies. With the euro weakening against the dollar and, to a lesser extent, the pound and the yen, the franc depreciated by about 5 percent in nominal and real effective terms.

Following a series of deficits and rising debt through the 1990 s, fiscal policy is now on a moderately contractionary medium-term path set by the 1998 constitutional commitment to balance the Confederation budget by 2001 . The general government deficit is estimated at 1.4 percent of GDP in 1999.

The outlook for the Swiss economy is favorable. Real GDP growth is projected to strengthen from 11/2 percent in 1999 to above-trend rates close to 2 percent in 2000-01 on the strength of faster growth of exports and investment, and buoyant growth in private consumption. Inflation is likely to rise to $1 \frac{1}{3}$ percent in 2000 , reflecting mainly the higher oil prices and the weakening of the exchange rate, and approach 1 percent on a core basis.

\section{Executive Board Assessment}

Executive Directors commended the authorities for sound macroeconomic policies, which have contributed to improved performance marked by rising output, falling unemployment, and low inflation, following a prolonged period of stagnation. Looking ahead, Directors noted that the main tasks are to maintain noninflationary economic recovery and to pursue very vigorously the structural reforms needed to strengthen Switzerland's long-term growth prospects by promoting competition and improving economic efficiency. 
Directors expected the upswing to strengthen in 2000 in response to an improving external environment. They considered that the current stance of macroeconomic policies provides a fair degree of insurance against risks to medium-term price stability, given ongoing fiscal consolidation and the recent steps to tighten monetary policy by the Swiss National Bank (SNB). Directors considered that continued vigilance will be needed and some further firming of monetary conditions warranted in due course as remaining economic slack is absorbed.

Directors welcomed the new monetary policy framework that focuses primarily on the goal of medium-term price stability and uses an inflation forecast to guide policy decisions. They considered that the announcement of the inflation forecast and objectives for the three-month reference interest rate provides a useful clarification of the authorities' intentions with regard to the conduct of monetary policy. In light of the relatively wide band chosen for the reference interest rate, Directors encouraged the SNB to continue to communicate changes in its policy stance clearly and in a timely fashion. They also suggested that the authorities make periodic presentations of the analytic framework used to generate the inflation forecasts.

Directors noted the further increase in Switzerland's large current account surplus that reflects primarily income from a strong foreign asset position. They stressed that structural reforms, including the removal of product market rigidities that discourage domestic investment, would be crucial in helping to reduce the surplus and strengthen growth prospects. Some Directors underscored that such efforts would allow Switzerland to play a greater role in fostering the correction of global external imbalances. Directors agreed that, in light of the strong external position, some moderate appreciation of the Swiss franc on a multilateral basis would not be a cause for concem.

Directors welcomed the progress in reducing the budget deficit in line with the constitutional mandate to balance the Confederation's budget by 2001, and underscored the importance of a continued commitment to fiscal consolidation in order to sustain market confidence. They agreed that the fiscal policy framework beyond 2001 should aim at balancing the Confederation's budget over the business cycle and should ensure that automatic stabilizers are allowed to operate. Directors therefore welcomed the authorities' plans to set medium-term expenditure ceilings linked to the expected trend rate of economic growth, and to allow tax revenues and the deficit to fluctuate with the cycle; some Directors, however, were concerned that the planned policy might have only a limited effect at the lower levels of government, which have shown a tendency toward procyclical fiscal policy. More generally, Directors encouraged the authorities to strengthen the general budget process and control mechanisms. They also underscored the desirability of further reforming Switzerland's complex tax system and supported the authorities' emphasis on developing new mechanisms for facilitating tax base harmonization across cantons.

While acknowledging the important advantages of Switzerland's multi-pillar pension system, Directors noted that demographic developments would put significant pressure on the system's public pillar in the coming decades. They encouraged the authorities to take early action to ensure long-term sustainability. 
Directors welcomed the recent ratification of the bilateral agreements with the European Union (EU). They considered that the ongoing process of European monetary and economic integration would continue to affect Switzerland significantly regardless of any future decision on possible EU accession. Several Directors noted the many benefits that closer EU integration would bring, including facilitating a reduction in Swiss price levels. While Switzerland's labor market performance is stronger than in most EU countries, product market reforms are lagging, and Directors encouraged the authorities to speed up and deepen their efforts to remove rigidities in the economy's "sheltered" sectors. They pointed in this context to agriculture, where support levels remain considerably above even those in the EU; to competition policy, where the more proactive approach of the Competition Commission and proposals to reinforce further its powers are welcome; and to utilities, where recent reforms of telecommunications, rail, and postal services are steps in the right direction, and an accelerated timetable for the opening up of the electricity sector is desirable.

Directors noted that Switzerland's banking system remains well capitalized and internationally active banks well positioned. The domestic banking sector, however, faces significant challenges as the roles of guarantees and public ownership are likely to come increasingly into question. Directors therefore endorsed the extension of the supervisory mandate of the Federal Banking Commission to these banks. They also supported the recent step to improve supervision of the internationally active banks, as well as the intensification of efforts to combat money Jaundering.

Directors encouraged greater trade liberalization, particularly in agriculture, to enhance efficiency in the Swiss economy and improve economic prospects for developing countries.

While commending the authorities' generous provision of humanitarian assistance, Directors encouraged Switzerland to raise official development assistance to at least its own target of 0.4 percent of GDP.

Directors urged further efforts to improve the coverage and reliability of Swiss economic statistics, especially in the area of wage and government finance statistics, so as to strengthen the basis for sound economic management.

Public Information Notices (PINs) are issued, (i) at the request of a member country, following the conclusion of the Article IV consultation for countries seeking to make known the views of the IMF to the public. This action is intended to strengthen IMF surveillance over the economic policies of member countries by increasing the transparency of the IMF's assessment of these policies; and (ii) following policy discussions in the Executive Board at the decision of the Board. As part of a pilot project, the staff report (use the free Adobe Acrobat Reader to view this pdf file) for the 1999 Article IV consultation with Switzerland is also available. 
Switzerland: Selected Economic Indicators

\begin{tabular}{|c|c|c|c|c|c|c|}
\hline & 1995 & 1996 & 1997 & 1998 & $19991 /$ & 200011 \\
\hline \multicolumn{7}{|l|}{ Real economy } \\
\hline Real GDP & 0.5 & 0.3 & 1.7 & 2.1 & 1.4 & 2.0 \\
\hline Real total domestic demand & 1.8 & 0.4 & 1.3 & 4.1 & 1.9 & 1.4 \\
\hline $\mathrm{CPI}$ (year average) & 1.8 & 0.8 & 0.5 & 0.1 & 0.8 & 1.3 \\
\hline Unemployment rate (in percent of labor force) & 4.2 & 4.7 & 5.2 & 3.9 & 2.7 & 2.3 \\
\hline Gross national saving (percent of GDP) & 28.4 & 27.7 & 30.3 & 30.3 & 33.2 & 30.6 \\
\hline Gross national investment (percent of GDP) & 21.4 & 20.3 & 20.2 & 21.2 & 20.1 & 20.6 \\
\hline \multicolumn{7}{|l|}{ Public finances (percent of GDP) } \\
\hline Confederation budget balance $2 /$ & -1.3 & -1.6 & -1.5 & -0.7 & -0.9 & -0.6 \\
\hline General government balance $2 / 3 /$ & -1.9 & -1.9 & -2.4 & -1.1 & -1.4 & -1.2 \\
\hline Gross public debt & 46.9 & 49.3 & 51.5 & 53.8 & 54.0 & 53.4 \\
\hline \multicolumn{7}{|l|}{ Batance of payments } \\
\hline Trade balance (in percent of GDP) & 0.3 & 0.3 & -0.1 & -0.6 & 0.0 & -0.2 \\
\hline Current account (in percent of GDP) & 7.0 & 7.4 & 10.1 & 9.1 & 13.1 & 10.0 \\
\hline Official reserves (end of year, US $\$$ billion) 4 I & 36.4 & 38.4 & 39.0 & 41.2 & 36.3 & $\cdots$ \\
\hline \multicolumn{7}{|l|}{ Money and interest rates } \\
\hline Monetary base (end of year) & 1.4 & 5.2 & 2.7 & 4.0 & 4.7 & $\ldots$ \\
\hline M3 (end of year) & 3.1 & 6.7 & 3.4 & 0.4 & 0.0 & ... \\
\hline Three-month euro rate (in percent) & 3.0 & 1.9 & 1.6 & 1.5 & 1.4 & $\ldots$ \\
\hline Government bond yield (in percent) & 4.8 & 4.2 & 3.5 & 2.9 & 2.9 & $\ldots$ \\
\hline \multicolumn{7}{|l|}{ Exchange rate } \\
\hline Exchange rate regime & \multicolumn{6}{|c|}{ Managed float } \\
\hline Present rate (February 14,2000$)$ & & & $N F 1.63$ & US\$ & & \\
\hline Nominal effective exchange rate $(1990=100)$ & 112.8 & 111.1 & 104.3 & 107.0 & 105.3 & $\ldots$ \\
\hline Real effective exchange rate $(1990=100) 5 /$ & 112.2 & 109.1 & 100.9 & 102.1 & 100.4 & $\ldots$ \\
\hline
\end{tabular}

1/ Staff estimates and projections.

2/Excluding privatization revenue.

$3 /$ Including Confederation, cantons, communes, and social security.

4/ Excluding gold.

5/ Based on consumer prices. 